\title{
Asymmetric CuH-Catalyzed Hydrosilylations en route to Amphidinoketide I
}

Bruce H. Lipshutz, ${ }^{*}$ Ching-Tien Lee, and Jeff M. Servesko

Department of Chemistry and Biochemistry

University of California, Santa Barbara, CA 93106

Supporting Information 
General. All experiments were conducted under an argon atmosphere, in oven dried glassware with magnetic stirring, unless otherwise specified. Reagents obtained from commercial sources were purified before use unless otherwise noted, except organometallic reagents which were used as received from Aldrich in Sure-Seal bottles. Chromatography (TLC) was performed using EM Science 60-F254 (250 nm) silica gel precoated plates; EM Science cat. No. 5714-3. Flash chromatography was performed using silica gel; 200-425 mesh, 60Á Grade 633 available from Fisher Scientific. Flash chromatography columns were slurry packed. FT-IR spectra were recorded using a Mattson Infinity M60t instrument with either neat samples on $\mathrm{NaCl}$ plates, $\mathrm{KBr}$ pellets, or dilute chloroform solutions. HRMS spectra were recorded at the UCSB mass spectrometry facility by Dr. James Pavlovich using a Micromass VG 70e magnetic sector by EI, CI (using $\mathrm{CH}_{4}$ ), or FAB (using NBA) standard methods. NMR spectra were recorded using Varian Inova spectrometers either at 400 or $500 \mathrm{MHz}$ for ${ }^{1} \mathrm{H}$, with dilute solutions in $\mathrm{CDCl}_{3}$ or $\mathrm{CD}_{2} \mathrm{Cl}_{2}$ (3 $\mathrm{mm}$ or $5 \mathrm{~mm}$ tubes). Chemical shifts are referenced to recognized solvent peaks.

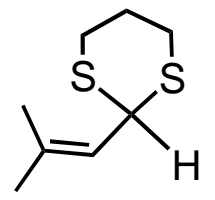

2-(2-Methylprop-1-enyl)-1,3-dithiane, 7. To a flame-dried, argon-purged RBF (25 mL) was added $\mathrm{CH}_{2} \mathrm{Cl}_{2}(5 \mathrm{~mL})$ and 3-methyl-2-butenal $(500 \mathrm{mg}, 5.9 \mathrm{mmol}), 1,3$-propanedithiol $(0.48 \mathrm{~mL}, 5.8 \mathrm{mmol})$ and zinc trifluoromethanesulfonate $(257 \mathrm{mg}, 0.7 \mathrm{mmol})$. The reaction was allowed to stir at $\mathrm{rt}$ for $2 \mathrm{~h}$ and then quenched by addition of $\mathrm{NaHCO}_{3}$ (sat.). The aqueous layer was extracted twice with $\mathrm{Et}_{2} \mathrm{O}$ and the combined organic layers were washed with brine, dried over anhydrous $\mathrm{MgSO}_{4}$, filtered, and concentrated via rotary evaporation. Flash chromatography on silica gel with pet ether:ethyl acetate (9:1; $\left.\mathrm{R}_{f}=0.40\right)$ provides the title compound $(920 \mathrm{mg}, 90 \%)$ as a clear oil. IR (neat): $2969,2898,1664,1422$, $1167 \mathrm{~cm}^{-1} ;{ }^{1} \mathrm{H}$ NMR $\left(\mathrm{CDCl}_{3}, 400 \mathrm{MHz}\right): \delta 1.75(\mathrm{~s}, 6 \mathrm{H}), 1.80-1.88(\mathrm{~m}, 1 \mathrm{H}), 2.06-2.12(\mathrm{~m}, 1 \mathrm{H}), 2.77-2.82$ $(\mathrm{m}, 2 \mathrm{H}), 2.91-2.98(\mathrm{~m}, 2 \mathrm{H}), 4.87(\mathrm{~d}, J=10 \mathrm{~Hz}, 1 \mathrm{H}), 5.13(\mathrm{~d}, J=10 \mathrm{~Hz}, 1 \mathrm{H}) ;{ }^{13} \mathrm{C} \mathrm{NMR}\left(\mathrm{CDCl}_{3}, 100\right.$ $\mathrm{MHz}): \delta 18.62,25.19,25.88,30.82,44.64,121.34,138.06 ;$ EIMS m/z (\%): 44 (77), 84 (77), 98 (100), 126 (27), 173 (14), 174 (5); HRMS Calcd for $\mathrm{C}_{8} \mathrm{H}_{14} \mathrm{~S}_{2}$ 174.0537; Found 174.0538 [M] $]^{+}$.

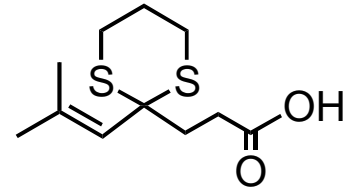

3-(2-(2-Methylprop-1-enyl)-1,3-dithian-2-yl)propanoic acid, 8. To a flame-dried, argon-purged RBF $(100 \mathrm{~mL})$ was added THF $(40 \mathrm{~mL})$ and $7(4.6 \mathrm{~g}, 26.4 \mathrm{mmol})$. The solution was cooled to $-30{ }^{\circ} \mathrm{C}$ and $n$ BuLi (10.36 mL, $26.4 \mathrm{mmol})$ was added dropwise. After $90 \mathrm{~min}$ of stirring, a solution of 3bromopropanoic acid $(2 \mathrm{~g}, 13.2 \mathrm{mmol})$ in THF $(5 \mathrm{~mL})$ was added slowly. The mixture was allowed to warm to $\mathrm{rt}$ and stir for $8 \mathrm{~h}$ before quenching with $\mathrm{NH}_{4} \mathrm{Cl}$ (sat.). The aqueous layer was extracted twice with $\mathrm{CH}_{2} \mathrm{Cl}_{2}$ and the combined organic layers were washed with brine, dried over anhydrous $\mathrm{MgSO}_{4}$, filtered, and concentrated via rotary evaporation. Flash chromatography on silica gel with $\mathrm{CH}_{2} \mathrm{Cl}_{2}$ : $\operatorname{MeOH}\left(9: 1 ; \mathrm{R}_{f}=0.50\right)$ provided the title compound $(2.4 \mathrm{~g}, 74 \%)$ as a clear oil. IR (neat): 3050 (br), 2928, 1708, 1421, 1265, $739 \mathrm{~cm}^{-1}$; ${ }^{1} \mathrm{H} \mathrm{NMR}\left(\mathrm{CDCl}_{3}, 400 \mathrm{MHz}\right): 1.77$ (d, J=1.2 Hz, 3H), 1.86-1.97 (m, 2H), $2.01(\mathrm{~d}, J=1.2 \mathrm{~Hz}, 3 \mathrm{H}), 2.51(\mathrm{~d}, J=9.2,2 \mathrm{H}), 2.57(\mathrm{~d}, J=9.2,2 \mathrm{H}), 2.72(\mathrm{dq}, J=14.4,2.8 \mathrm{~Hz}, 2 \mathrm{H})$, $2.98(\mathrm{qd}, J=14,2.8 \mathrm{~Hz}, 2 \mathrm{H}), 5.25(\mathrm{~s}, 1 \mathrm{H}) ;{ }^{13} \mathrm{C} \mathrm{NMR}\left(\mathrm{CDCl}_{3}, 100 \mathrm{MHz}\right): \delta 20.24,25.16,27.62,27.88$, 30.86, 34.86, 51.61, 125.61, 141.64, 180.24; EIMS m/z(\%): 99 (100), 111 (51), 112 (71), 173 (41), 246 (87); HRMS Calcd for $\mathrm{C}_{11} \mathrm{H}_{18} \mathrm{O}_{2} \mathrm{~S}_{2} 246.0748$; Found 246.0747 [M] 


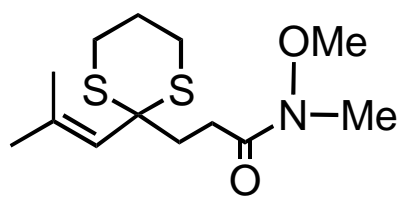

N-Methoxy-N-methyl-3-(2-(2-methylprop-1-enyl)-1,3-dithian-2-yl)propanamide, 9. To a flame-dried, argon-purged RBF $(100 \mathrm{~mL})$ was added $\mathrm{CH}_{2} \mathrm{Cl}_{2}(50 \mathrm{~mL})$ and 8 (4.0 g, $\left.16 \mathrm{mmol}\right)$, EDCI (4.0 g, 24 mmol), diisopropylethylamine $(4.0 \mathrm{~mL}, 24 \mathrm{mmol})$, and catalytic DMAP (50 $\mathrm{mg}, 0.4 \mathrm{mmol})$. The solution was allowed to stir at $\mathrm{rt}$ for $15 \mathrm{~min}$ and $\mathrm{HCl} \cdot \mathrm{HN}\left(\mathrm{OCH}_{3}\right) \mathrm{CH}_{3}(2.29 \mathrm{~g}, 24 \mathrm{mmol})$ was added. The reaction was stirred for $4 \mathrm{~h}$ and quenched by addition of $\mathrm{NH}_{4} \mathrm{Cl}$ (sat.). The aqueous layer was extracted twice with $\mathrm{CH}_{2} \mathrm{Cl}_{2}$ and the combined organic layers were washed with brine, dried over anhydrous $\mathrm{MgSO}_{4}$, filtered, and concentrated via rotary evaporation. Flash chromatography on silica gel with pet ether:ethyl acetate $\left(65: 35 ; \mathrm{R}_{f}=0.30\right)$ provides the title compound $(2.9 \mathrm{~g}, 64 \%)$ as a white solid. IR (neat): 2931, 1652, 1445, 1384, 1174, $995 \mathrm{~cm}^{-1} ;{ }^{1} \mathrm{H} \mathrm{NMR}\left(\mathrm{CDCl}_{3}, 400 \mathrm{MHz}\right): \delta 1.73(\mathrm{~d}, J=1.2 \mathrm{~Hz}, 3 \mathrm{H})$, 1.86-1.92 (m, 2H), $1.98(\mathrm{~d}, J=1.2 \mathrm{~Hz}, 3 \mathrm{H}), 2.43-2.47(\mathrm{~m}, 2 \mathrm{H}), 2.57-2.60(\mathrm{~m} 2 \mathrm{H}), 2.67(\mathrm{dq}, J=14.4$, $2.8 \mathrm{~Hz}, 2 \mathrm{H}), 2.97(\mathrm{qd}, J=10,2.8 \mathrm{~Hz}, 2 \mathrm{H}), 3.16(\mathrm{~s}, 3 \mathrm{H}), 3.67(\mathrm{~s}, 3 \mathrm{H}), 5.26(\mathrm{~s}, 1 \mathrm{H}) ;{ }^{13} \mathrm{C} \mathrm{NMR}\left(\mathrm{CDCl}_{3}\right.$, $100 \mathrm{MHz}): \delta 20.26,25.21,27.55,27.86,28.65,32.44,34.73,51.97,61.45,125.98,141.25,174.30$; EIMS m/z(\%): 95 (24), 106 (20), 110 (27), 152 (100), 154 (33), 172 (44), 183 (51), 289 (28); HRMS Calcd for $\mathrm{C}_{13} \mathrm{H}_{23} \mathrm{NO}_{2} \mathrm{~S}_{2} 289.1170$; Found 289.1161 [M] $]^{+}$.

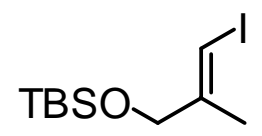

(E)-tert-Butyl(3-iodo-2-methylallyloxy)dimethylsilane, 6. To a flame-dried, argon-purged RBF (1 L) was added $\mathrm{CH}_{2} \mathrm{Cl}_{2}(100 \mathrm{~mL})$ and $\mathrm{Cp}_{2} \mathrm{ZrCl}_{2}(3.78 \mathrm{~g}, 12.9 \mathrm{mmol})$. The above solution was cooled to $0^{\circ} \mathrm{C}$ and $\mathrm{Me}_{3} \mathrm{Al}(2 \mathrm{M}$ in toluene, $77.6 \mathrm{~mL}, 155 \mathrm{mmol}$ ) was added dropwise followed by addition of a solution of propargyl alcohol ( $3 \mathrm{~mL}, 51.5 \mathrm{mmol})$ in $100 \mathrm{~mL} \mathrm{CH}_{2} \mathrm{Cl}_{2}$. The mixture was warmed up to $\mathrm{rt}$ and let it stir $18 \mathrm{~h}$. The color of solution turned brown and was cooled to $-30^{\circ} \mathrm{C}$ before $\mathrm{I}_{2}(19.6 \mathrm{~g}, 77.3 \mathrm{mmol})$ was added. After $3 \mathrm{~h}$ stirring at $\mathrm{rt}$, the solution was quenched by potassium sodium tartrate (sat.) to give a heterogeneous solution. The mixture was filtered through celite and filter cake was further rinsed with $\mathrm{Et}_{2} \mathrm{O}$. The aqueous layer was extracted twice with $\mathrm{CH}_{2} \mathrm{Cl}_{2}$ and the combined organic layers were washed with brine, dried over anhydrous $\mathrm{MgSO}_{4}$, filtered, and concentrated via rotary evaporation to give crude product $(4.8 \mathrm{~g})$. Further purification was not necessary. The mixture obtained from above was diluted with $\mathrm{CH}_{2} \mathrm{Cl}_{2}(100 \mathrm{~mL})$ and TBSCl $(3.6 \mathrm{~g}, 24.5 \mathrm{mmol})$ and imidazol (1.7 g, $\left.24.5 \mathrm{mmol}\right)$ was added. The solution was allowed to stir at $\mathrm{rt}$ for $3 \mathrm{~h}$ and then quenched with $\mathrm{NH}_{4} \mathrm{Cl}$ (sat.). The aqueous layer was extracted twice with $\mathrm{CH}_{2} \mathrm{Cl}_{2}$ and the combined organic layers were washed with brine, dried over anhydrous $\mathrm{MgSO}_{4}$, filtered, and concentrated via rotary evaporation. Flash chromatography on silica gel with pet ether $\left(\mathrm{R}_{f}=0.50\right)$ provides the title compound $(5.1 \mathrm{~g}, 31.1 \%)$ as a yellow oil. IR (neat): 2954 , 2829, 2857, 1513, 1471, 1252, $838 \mathrm{~cm}^{-1} ;{ }^{1} \mathrm{H} \mathrm{NMR}\left(\mathrm{CDCl}_{3}, 400 \mathrm{MHz}\right): \delta 0.07(\mathrm{~s}, 6 \mathrm{H}), 0.91(\mathrm{~s}, 9 \mathrm{H}), 1.78$ $(\mathrm{s}, 3 \mathrm{H}), 4.11(\mathrm{~s}, 2 \mathrm{H}), 6.20(\mathrm{~s}, 1 \mathrm{H}) ;{ }^{13} \mathrm{C} \mathrm{NMR}\left(\mathrm{CDCl}_{3}, 100 \mathrm{MHz}\right): \delta-5.24,18.52,21.33,26.04,67.27$, 76.12, 146.97; EIMS m/z(\%): 73 (72), 75 (44), 173 (34), 213 (53), 308 (100), 414 (53); HRMS Calcd for $\mathrm{C}_{6} \mathrm{H}_{12} \mathrm{IOSi}$ 254.9702; Found 254.9701 [M- $\left.\mathrm{C}_{4} \mathrm{H}_{9}\right]^{+}$. 


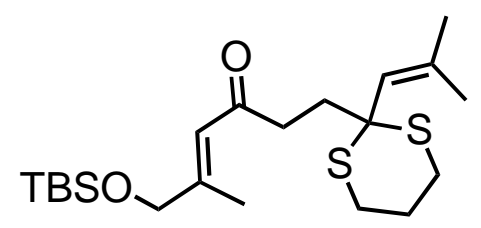

(E)-6-(tert-Butyldimethylsilyloxy)-5-methyl-1-(2-(2-methylprop-1-enyl)-1,3-dithian-2-yl)hex-4-en-3one, 10. To a flame-dried, argon-purged RBF $(100 \mathrm{~mL})$ was added THF $(8 \mathrm{~mL})$ and $6(1.4 \mathrm{~g}, 4.5 \mathrm{mmol})$. The solution was cooled to $-78^{\circ} \mathrm{C}$ and $n$-BuLi (1.76 g, $\left.4.5 \mathrm{mmol}\right)$ was added dropwise. After $20 \mathrm{~min}$, a solution of $9(0.65 \mathrm{~g}, 2.24 \mathrm{mmol})$ in THF $(8 \mathrm{~mL})$ was added. The mixture was allowed to stir at $-78{ }^{\circ} \mathrm{C}$ for $2 \mathrm{~h}$ and then quenched by buffer solution $(\mathrm{pH}=7)$. The aqueous layer was extracted twice with ether and the combined organic layers were washed with brine, dried over anhydrous $\mathrm{MgSO}_{4}$, filtered, and concentrated via rotary evaporation. Flash chromatography on silica gel (doped with TEA) with pet ether: ethyl acetate $\left(90: 10 ; \mathrm{R}_{f}=0.40\right)$ provides the title compound $(740 \mathrm{mg}, 79.8 \%)$ as a yellow oil. IR (neat): 2953, 2829, 2904, 2856, 1687, 1629, 1121, $778 \mathrm{~cm}^{-1} ;{ }^{1} \mathrm{H}$ NMR ( $\left.\mathrm{CDCl}_{3}, 400 \mathrm{MHz}\right): \delta 0.09$ (s, 6H), $0.94(\mathrm{~s}, 9 \mathrm{H}), 1.76(\mathrm{~d}, J=1.2 \mathrm{~Hz}, 3 \mathrm{H}), 1.87-1.96(\mathrm{~m}, 2 \mathrm{H}), 2.00(\mathrm{~d}, J=1.2 \mathrm{~Hz}, 3 \mathrm{H}), 2.02(\mathrm{~s}, 3 \mathrm{H}), 2.45-$ $2.49(\mathrm{~m}, 2 \mathrm{H}), 2.65-2.69(\mathrm{~m}, 2 \mathrm{H}), 2.72(\mathrm{q}, J=3.2 \mathrm{~Hz}, 2 \mathrm{H}), 2.98(\mathrm{qd}, J=10,2.8 \mathrm{~Hz}, 2 \mathrm{H}), 4.10(\mathrm{~s}, 2 \mathrm{H})$, $5.27(\mathrm{~s}, 1 \mathrm{H}), 6.40(\mathrm{~s}, 1 \mathrm{H}) ;{ }^{13} \mathrm{C} \mathrm{NMR}\left(\mathrm{CDCl}_{3}, 100 \mathrm{MHz}\right): \delta-5.22,16.19,18.59,20.24,25.25,26.08$, 27.63, 27.85, 34.28, 40.94, 52.04, 67.24, 120.46, 126.17, 141.16, 155.84, 200.77; EIMS m/z(\%): 73 (72), 75 (44), 173 (34), 176 (36), 213 (53), 308 (100), 414 (53); HRMS Calcd for $\mathrm{C}_{21} \mathrm{H}_{38} \mathrm{O}_{2} \mathrm{~S}_{2} \mathrm{Si}$ 414.2082; Found $414.2073[\mathrm{M}]^{+}$.

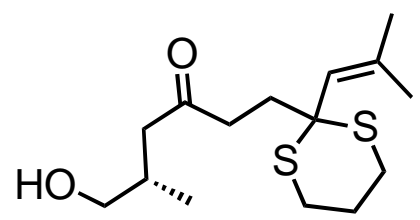

(S)-6-Hydroxy-5-methyl-1-(2-(2-methylprop-1-enyl)-1,3-dithian-2-yl)hexan-3-one, 11. To a flamedried, argon-purged RBF (10 mL) was added $\mathrm{CuCl}(18 \mathrm{mg}, 0.18 \mathrm{mmol}), \mathrm{NaO}-t-\mathrm{Bu}(18 \mathrm{mg}, 0.18 \mathrm{mmol})$, $(R, S)-\mathrm{PPF}-\mathrm{P}(t-\mathrm{Bu})_{2}(53 \mathrm{mg}, 0.097 \mathrm{mmol})$ and THF $(1.5 \mathrm{~mL})$. The solution was cooled to $0{ }^{\circ} \mathrm{C}$ and stirred for $30 \mathrm{~min}$. PMHS $(23 \mu \mathrm{L}, 0.36 \mathrm{mmol})$ was added and the solution was allowed to stir for another $5 \mathrm{~min}$ before being cooled to $-30{ }^{\circ} \mathrm{C}$. Compound $10(740 \mathrm{mg}, 1.78 \mathrm{mmol})$ was diluted with THF $(1 \mathrm{~mL})$ and then transferred to the above solution at $-30{ }^{\circ} \mathrm{C}$ followed by the addition of PMHS $(210$ $\mu \mathrm{L}, 3.2 \mathrm{mmol}$ ). The reaction was stirred until complete (monitored by $\mathrm{TLC}, \mathrm{R}_{\mathrm{f}}=0.50,10 \%$ ethyl acetate/pet ether, $7 \mathrm{~h}$ ). The reaction was then quenched with $\mathrm{NaHCO}_{3}$ (sat.) and ether, and stirred for 1 $\mathrm{h}$ at $\mathrm{rt}$. The aqueous layer was extracted twice with ether and the combined organic layers were washed with brine, dried over anhydrous $\mathrm{MgSO}_{4}$, filtered, and concentrated via rotary evaporation to give crude product $(720 \mathrm{mg})$. The material was diluted with THF $(1 \mathrm{~mL})$ and TBAF $(1 \mathrm{M}$ in THF, $9 \mathrm{~mL}, 9 \mathrm{mmol})$ was added. The reaction was monitored by TLC $(1 \mathrm{~h}, 35 \%$ ethyl acetate/pet ether) and quenched by addition of $\mathrm{NaHCO}_{3}$ (sat.). The aqueous layer was extracted twice with ether and the combined organic layers were washed with brine, dried over anhydrous $\mathrm{MgSO}_{4}$, filtered, and concentrated via rotary evaporation. Flash chromatography on silica gel with pet ether:ethyl acetate $\left(65: 35 ; \mathrm{R}_{f}=0.30\right)$ provided the title compound (500 mg, 93\%) as a clear oil. [ $\alpha]_{\mathrm{D}}^{20}+1$ (c 2, $\mathrm{CHCl}_{3}$ ); IR (neat): 3424 (br), 2933, 2908, 1708, 1651, 1374, 1041 $\mathrm{cm}^{-1}$; ${ }^{1} \mathrm{H}$ NMR $\left(\mathrm{CDCl}_{3}, 400 \mathrm{MHz}\right): \delta 0.87(\mathrm{~d}, \mathrm{~J}=6.8 \mathrm{~Hz}, 3 \mathrm{H}), 1.70(\mathrm{~s}, 3 \mathrm{H}), 1.82-$ $1.92(\mathrm{~m}, 2 \mathrm{H}), 1.94(\mathrm{~s}, 3 \mathrm{H}), 2.15-2.19(\mathrm{~m}, 1 \mathrm{H}), 2.32-2.41(\mathrm{~m}, 4 \mathrm{H}), 2.53-2.58(\mathrm{~m}, 3 \mathrm{H}), 2.62(\mathrm{dq}, J=14.8$, $2.8 \mathrm{~Hz}, 2 \mathrm{H}), 2.91(\mathrm{qd}, J=10.4,2.8,2 \mathrm{H}), 3.34(\mathrm{dd}, J=10.4,7.2 \mathrm{~Hz}, 1 \mathrm{H}), 3.50(\mathrm{dd}, J=10.4,5.2,1 \mathrm{H})$, $5.18(\mathrm{~s}, 1 \mathrm{H}) ;{ }^{13} \mathrm{C} \mathrm{NMR}\left(\mathrm{CDCl}_{3}, 100 \mathrm{MHz}\right): \delta 17.15,20.24,25.14,27.67,27.85,32.13,33.89,39.73$, 47.41, 51.99, 68.08, 126.09, 141.39, 210.86; EIMS m/z(\%): 54 (11), 98 (16), 111 (72), 172 (38), 195 (100), 302 (9); HRMS Calcd for $\mathrm{C}_{15} \mathrm{H}_{26} \mathrm{O}_{2} \mathrm{~S}_{2}$ 302.1374; Found 302.1385 [M] $]^{+}$. The ee was determined 
on a Daicel Chiralcel OD-R column $\left(2.5 \% \mathrm{IPA} / \mathrm{hexane}, 1 \mathrm{~mL} / \mathrm{min}, \mathrm{R}_{\mathrm{t}}=22.965 \mathrm{~min}\right.$ (major) and 26.283 $\min$ ): $94.7 \%$.

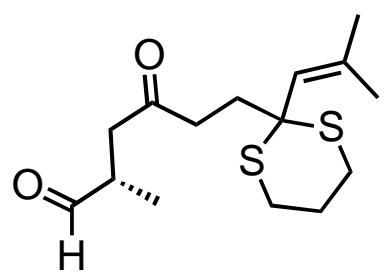

(S)-2-Methyl-6-(2-(2-methylprop-1-enyl)-1,3-dithian-2-yl)-4-oxohexanal, 12. To a $50 \mathrm{~mL}$ RBF was added compound 11 (290 mg, $0.96 \mathrm{mmol}$ ), sulfur trioxide pyridine complex (305 mg, $2 \mathrm{mmol}$ ), TEA $(486 \mu \mathrm{L}, 3.5 \mathrm{mmol})$ and DMSO $(10 \mathrm{~mL})$. The solution was allowed to stir at $\mathrm{rt}$ for $4 \mathrm{~h}$ and then quenched with $\mathrm{NaHCO}_{3}$ (sat.) (use of sat. $\mathrm{NH}_{4} \mathrm{Cl}$ caused loss of the desired product). The aqueous layer was extracted twice with ether and the combined organic layers were washed with brine, dried over anhydrous $\mathrm{MgSO}_{4}$, filtered, and concentrated via rotary evaporation. Flash chromatography on silica gel with pet ether: ethyl acetate $\left(65: 35 ; \mathrm{R}_{f}=0.70\right)$ provided the title compound $(240 \mathrm{mg}, 83 \%)$ as a clear oil. $[\alpha]^{20}{ }_{\mathrm{D}}+31.5$ (c 2.5, $\mathrm{CHCl}_{3}$ ); IR (neat): 2928, 2859, 2715, 1712, 1650, $1278 \mathrm{~cm}^{-1} ;{ }^{1} \mathrm{H} \mathrm{NMR}\left(\mathrm{CDCl}_{3}, 400\right.$ $\mathrm{MHz}): \delta 1.14(\mathrm{~d}, J=7.6 \mathrm{~Hz}, 3 \mathrm{H}), 1.76(\mathrm{~s}, 3 \mathrm{H}), 1.79-1.94(\mathrm{~m}, 2 \mathrm{H}), 2.00(\mathrm{~s}, 3 \mathrm{H}), 2.43-2.55(\mathrm{~m}, 3 \mathrm{H}), 2.61-$ $2.69(\mathrm{~m}, 4 \mathrm{H}), 2.89-2.98(\mathrm{~m}, 4 \mathrm{H}), 5.22(\mathrm{~s}, 1 \mathrm{H}), 9.68(\mathrm{~s}, 1 \mathrm{H}) ;{ }^{13} \mathrm{C} \mathrm{NMR}\left(\mathrm{CDCl}_{3}, 100 \mathrm{MHz}\right): \delta 13.74$, 20.34, 25.12, 27.73, 27.91, 33.91, 39.41, 41.77, 43.85, 51.92, 126.00, 141.65, 203.62, 208.05; EIMS m/z(\%): 111 (100), 136 (17), 172 (22), 299 (35), 300 (9); HRMS Calcd for $\mathrm{C}_{15} \mathrm{H}_{24} \mathrm{O}_{2} \mathrm{~S}_{2} 300.1218$; Found $300.1207[\mathrm{M}]^{+}$

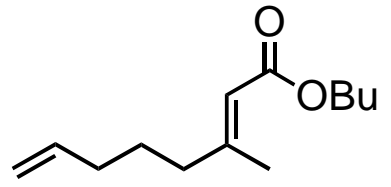

(E)-Butyl 3-methyloct-7-enoate, 14. To a flame-dried, argon-purged RBF (500 mL) was added $\mathrm{Cp}_{2} \mathrm{ZrCl}_{2}(3.8 \mathrm{~g}, 13.01 \mathrm{mmol})$, and $\mathrm{CH}_{2} \mathrm{Cl}_{2}(110 \mathrm{~mL})$. The mixture was stirred for 10 min until clear and then cooled to $0{ }^{\circ} \mathrm{C}$ for $10 \mathrm{~min}$. $\mathrm{Me}_{3} \mathrm{Al}(40 \mathrm{~mL}, 80 \mathrm{mmol}$ in hexanes) was then added. The yellow solution was stirred $10 \mathrm{~min}$ and $\mathrm{H}_{2} \mathrm{O}(140 \mu \mathrm{L}, 7.77 \mathrm{mmol}$ ) was added (caution, violent exotherm!), the reaction mixture was stirred at $0{ }^{\circ} \mathrm{C}$ for $30 \mathrm{~min}$ and 6-hexene-1-yne $(7 \mathrm{~mL}, 53.62 \mathrm{mmol}$, neat) was added. The reaction was stirred $3 \mathrm{~h}$, warming slowly to $\mathrm{rt}$ during which it darkened to yellow-orange. Gas chromatography showed complete consumption of alkyne. The mixture was cooled to $0{ }^{\circ} \mathrm{C}$ for 10 min and a mixture of DMAP (2 mg, $0.016 \mathrm{mmol})$ and $n$-butyl chloroformate $(8.52 \mathrm{~mL}, 67.0 \mathrm{mmol})$ was added dropwise. The reaction was allowed to warm to $\mathrm{rt}$ over $24 \mathrm{~h}$ and then analyzed by TLC (15\% $\left.\mathrm{CH}_{2} \mathrm{Cl}_{2}, 85 \% \mathrm{PE}, \mathrm{R}_{f}=0.20\right)$ which showed formation of product with a small amount of alkene intermediate remaining. The mixture was poured slowly into ice and $\mathrm{NaHCO}_{3} / \mathrm{Et}_{2} \mathrm{O}$ and stirred for $2 \mathrm{~h}$. The aqueous layer was extracted twice with $\mathrm{Et}_{2} \mathrm{O}$ and the combined organic layers were washed with brine, dried over anhydrous $\mathrm{MgSO}_{4}$, filtered, and concentrated by rotary evaporation. Flash chromatography on $\mathrm{SiO}_{2}\left(12.5 \% \mathrm{CH}_{2} \mathrm{Cl}_{2} / \mathrm{PE}\right)$ produced the target compound $(7.70 \mathrm{~g}, 86 \%)$ as a clear oil. IR (neat): 3040, 2990, 2860, 1710, 1660, 1460, 1440, 1220, 1150, $920 \mathrm{~cm}^{-1} ;{ }^{1} \mathrm{H}$ NMR $\left(\mathrm{C}_{6} \mathrm{D}_{6}, 400 \mathrm{MHz}\right)$ : $\delta 0.76(\mathrm{t}, J=7.7 \mathrm{~Hz}, 3 \mathrm{H}), 1.17-1.31(\mathrm{~m}, 4 \mathrm{H}), 1.41-1.51(\mathrm{~m}, 2 \mathrm{H}), 1.74-1.83(\mathrm{~m}, 4 \mathrm{H}), 2.17(\mathrm{~d}, J=1.1 \mathrm{~Hz}$, $3 \mathrm{H}), 4.10(\mathrm{t}, J=6.1 \mathrm{~Hz}, 2 \mathrm{H}), 4.91-5.02(\mathrm{~m}, 2 \mathrm{H}), 5.56-5.58(\mathrm{~m}, 1 \mathrm{H}), 5.81(\mathrm{q}, J=1.1 \mathrm{~Hz}, 1 \mathrm{H}) ;{ }^{13} \mathrm{C}$ NMR $\left(\mathrm{CDCl}_{3}, 125 \mathrm{MHz}\right): \delta 13.86,18.80,19.36,26.69,30.93,33.29,40.37,63.54,115.15,115.87,138.22$, 159.79, 167.05; EIMS m/z(\%): 54(40), 67(42), 84(100), 95(64), 137(25), 154(5); HRMS Calcd for $\mathrm{C}_{13} \mathrm{H}_{23} \mathrm{O}_{2} 211.1698$; Found 211.1700 [M+H] $]^{+}$. 


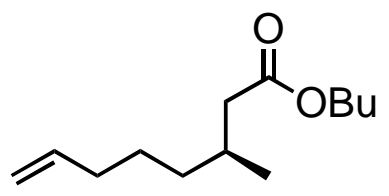

(3S)-Butylmethyl-oct-7-eneoate, 15. To a flame-dried, argon-purged RBF (5 mL) was added CuOAc (4 $\mathrm{mg}, 0.032 \mathrm{mmol}),(R, S)-\mathrm{PPF}-\mathrm{P}(t-\mathrm{Bu})_{2}(10 \mathrm{mg}, 0.02 \mathrm{mmol})$ and toluene $(1 \mathrm{~mL})$. The heterogeneous mixture was stirred for $20 \mathrm{~min}$ during which most solids dissolved. The reaction was cooled to $0{ }^{\circ} \mathrm{C}$ for $5 \mathrm{~min}$ and $t$-BuOH $(75 \mu \mathrm{L}, 0.784 \mathrm{mmol})$ was added followed by PMHS (120 $\mu \mathrm{L}, 2.7 \mathrm{mmol})$ and the reaction stirred $5 \mathrm{~min}$. A solution of $14(200 \mathrm{mg}, 0.95 \mathrm{mmol})$ in toluene $(0.25 \mathrm{~mL})$ was added via cannula and the reaction was stirred $3 \mathrm{~h}$ at $0{ }^{\circ} \mathrm{C}$. TLC $\left(15 \% \mathrm{CH}_{2} \mathrm{Cl}_{2} / \mathrm{PE}, \mathrm{R}_{f}=0.20\right)$ showed complete conversion (vanillin stain was necessary as $\mathrm{SM}$ and product have the same $\mathrm{R}_{f}$ ). The mixture was poured into $\mathrm{Et}_{2} \mathrm{O}$ and $\mathrm{NaHCO}_{3}$ (sat.) and stirred $30 \mathrm{~min}$. The aqueous layer was extracted twice with $\mathrm{Et}_{2} \mathrm{O}$ and the combined organic layers were washed with brine, dried over anhydrous $\mathrm{MgSO}_{4}$, filtered, and concentrated by rotary evaporation. Flash chromatography on $\mathrm{SiO}_{2}\left(12.5 \% \mathrm{CH}_{2} \mathrm{Cl}_{2} / \mathrm{PE}\right)$ produced the target compound (170 mg, 84\%) as a clear oil. IR (neat): 3077, 2960, 2931, 1736, 1641, 1460, 1199, 1171, $910 \mathrm{~cm}^{-1} ;{ }^{1} \mathrm{H}$ NMR $\left(\mathrm{C}_{6} \mathrm{D}_{6}, 500 \mathrm{MHz}\right): \delta 0.77(\mathrm{t}, J=7.6 \mathrm{~Hz}, 3 \mathrm{H}), 0.88(\mathrm{~d}, J=6.3 \mathrm{~Hz}, 3 \mathrm{H}), 0.98-$ $1.09(\mathrm{~m}, 1 \mathrm{H}), 1.14-1.31(\mathrm{~m}, 5 \mathrm{H}), 1.36-1.46(\mathrm{~m}, 2 \mathrm{H}), 1.86-2.04(\mathrm{~m}, 4 \mathrm{H}), 2.13-2.28(\mathrm{~m}, 1 \mathrm{H}), 4.02(\mathrm{t}, J=$ $6.6 \mathrm{~Hz}, 2 \mathrm{H}), 4.95-5.04(\mathrm{~m}, 2 \mathrm{H}), 5.67-5.79(\mathrm{~m}, 1 \mathrm{H}) ;{ }^{13} \mathrm{C} \mathrm{NMR}\left(\mathrm{CDCl}_{3}, 125 \mathrm{MHz}\right): \delta 13.19,19.28,19.80$, 26.33, 30.39, 30.83, 33.96, 36.25, 41.98, 64.09, 114.50, 138.84, 173.37; CIMS m/z(\%): 49(41), 97(44), 139(72), 157(45), 185(4), 213(21); HRMS Calcd for $\mathrm{C}_{13} \mathrm{H}_{25} \mathrm{O}_{2} 213.1849$; Found 213.1853[M+H] ${ }^{+}$.

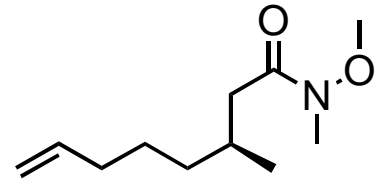

(S)-N-Methoxy-N,3-dimethyloct-7-enamide, 16. To a flame-dried, argon-purged RBF (5 mL) was added Weinreb's salt $(180 \mathrm{mg}, 1.84 \mathrm{mmol})$ and toluene $(1 \mathrm{~mL})$ and the reaction was cooled to $0{ }^{\circ} \mathrm{C}$ for 5 min. $\mathrm{Me}_{3} \mathrm{Al}(1.00 \mathrm{~mL}, 2.00 \mathrm{mmol}$ in toluene) was added dropwise with smoke and exotherm. The cloudy solution became clear over $20 \mathrm{~min}$. A solution of $15(130 \mathrm{mg}, 0.61 \mathrm{mmol})$ in toluene $(0.5 \mathrm{~mL})$ was added via cannula and the reaction allowed to warm to $\mathrm{rt}$ overnight. TLC $\left(25 \% \mathrm{EA} / \mathrm{hexanes}, \mathrm{R}_{f}=\right.$ $0.22)$ showed complete consumption. The mixture was poured into aqueous $\mathrm{HCl}(0.5 \mathrm{M})$ and $\mathrm{Et}_{2} \mathrm{O}$ and stirred $30 \mathrm{~min}$. The aqueous layer was extracted twice with $\mathrm{Et}_{2} \mathrm{O}$ and the combined organic layers were washed with brine, dried over anhydrous $\mathrm{MgSO}_{4}$, filtered, and concentrated by rotary evaporation. Flash chromatography on $\mathrm{SiO}_{2}(17 \% \mathrm{EA} /$ hexanes produced the target compound $(112 \mathrm{mg}, 92 \%)$ as a clear oil. Chiral GC \{Racemic $\mathrm{R}_{\mathrm{t}}$ : 168.8 and $171.3 \mathrm{~min}$; Chiral $\mathrm{R}_{\mathrm{t}}: 168.8$ and 170.26 (major)\} (GTA 95, 1 $\mathrm{mL} / \mathrm{min}$ ) showed 99\% ee. IR (neat): 3476, 3062, 2931, 1724, 1664, 1461, 1383, 1186, 1003, $910 \mathrm{~cm}^{-1}$; ${ }^{1} \mathrm{H} \mathrm{NMR}\left(\mathrm{CDCl}_{3}, 500 \mathrm{MHz}\right): \delta 0.92(\mathrm{~d}, J=6.1 \mathrm{~Hz}, 3 \mathrm{H}), 1.15-1.25(\mathrm{~m}, 1 \mathrm{H}), 1.30-1.48(\mathrm{~m}, 3 \mathrm{H}), 1.97-$ $2.05(\mathrm{~m}, 3 \mathrm{H}), 2.24(\mathrm{dd}, J=8.0$ and $14.4 \mathrm{~Hz}, 1 \mathrm{H}), 2.38(\mathrm{dd}, J=5.6$ and $14.4 \mathrm{~Hz}, 1 \mathrm{H}), 3.18(\mathrm{~s}, 3 \mathrm{H}), 3.66$ $(\mathrm{s}, 3 \mathrm{H}), 4.90-4.94(\mathrm{~m}, 1 \mathrm{H}), 4.96-5.01(\mathrm{~m}, 1 \mathrm{H}), 5.75-5.84(\mathrm{~m}, 1 \mathrm{H}) ;{ }^{13} \mathrm{C}$ NMR $\left(\mathrm{CDCl}_{3}, 125\right.$ MHz): $\delta 20.04,26.50,29.77,32.06,34.06,36.66,39.23,61.27,114.42,139.07,174.31$; EIMS $\mathrm{m} / \mathrm{z}(\%)$ : 55 (100), 69 (60), 111 (5), 139 (6); HRMS Calcd for $\mathrm{C}_{11} \mathrm{H}_{21} \mathrm{NO}_{2} \mathrm{Na} 222.1470$; Found $222.1475[\mathrm{M}+\mathrm{Na}]^{+}$. 


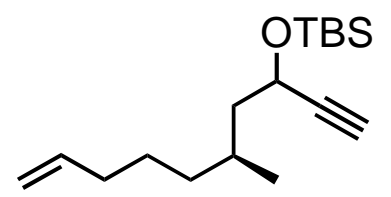

tert-Butyldimethyl((5S)-5-methyldec-9-en-1-yn-3-yloxy)silane, 4. To a flame-dried, argon-purged RBF $(50 \mathrm{~mL})$ was added $16(500 \mathrm{mg}, 2.5 \mathrm{mmol})$ and $\mathrm{CH}_{2} \mathrm{Cl}_{2}(2 \mathrm{~mL})$. The solution was cooled to $-78{ }^{\circ} \mathrm{C}$ and then DIBAL-H (1 M in hexane, $10 \mathrm{~mL}, 10 \mathrm{mmol})$ was added. The reaction was stirred until complete (monitored by TLC, $\mathrm{R}_{\mathrm{f}}=0.60,10 \%$ ethyl acetate/pet ether, $2 \mathrm{~h}$ ) and quenched with $\mathrm{MeOH}(0.3 \mathrm{~mL})$ at $78{ }^{\circ} \mathrm{C}$ and $\mathrm{KF}$ (2 M aq.). The mixture was allowed to warm to $\mathrm{rt}$ and stirred for $2 \mathrm{~h}$. The aqueous layer was extracted twice with $\mathrm{CH}_{2} \mathrm{Cl}_{2}$ and the combined organic layers were washed with brine, dried over anhydrous $\mathrm{MgSO}_{4}$, filtered, and concentrated by rotary evaporation to give the crude corresponding aldehyde (caution: volatile). Crude product was diluted with THF (2 mL) and ethynylmagnesium bromide $(0.5 \mathrm{M}$ in THF, $25 \mathrm{~mL}, 12.5 \mathrm{mmol})$ was added. The reaction was stirred at $\mathrm{rt}$ until complete (monitored by TLC, $\mathrm{R}_{\mathrm{f}}=0.20,10 \%$ ethyl acetate/pet ether) and then quenched by $\mathrm{NH}_{4} \mathrm{Cl}$ (sat.). The aqueous layer was extracted twice with $\mathrm{Et}_{2} \mathrm{O}$ and the combined organic layers were washed with brine, dried over anhydrous $\mathrm{MgSO}_{4}$, filtered, and concentrated by rotary evaporation to give the crude corresponding alcohol $(300 \mathrm{mg})$. The crude alcohol was diluted with $\mathrm{CH}_{2} \mathrm{Cl}_{2}(5 \mathrm{~mL})$ and TBSCl (300 $\mathrm{mg}, 2 \mathrm{mmol})$, imidazole $(142 \mathrm{mg}, 2.1 \mathrm{mmol})$ was added. After $1 \mathrm{~h}$, the reaction was quenched by $\mathrm{NH}_{4} \mathrm{Cl}$ (sat.). The aqueous layer was extracted twice with $\mathrm{CH}_{2} \mathrm{Cl}_{2}$ and the combined organic layers were washed with brine, dried over anhydrous $\mathrm{MgSO}_{4}$, filtered, and concentrated via rotary evaporation. Flash chromatography on silica gel with pet ether: ethyl acetate $\left(95: 5 ; \mathrm{R}_{f}=0.70\right)$ provides the title compound (440 mg, 63\%) as a clear oil. IR (neat): 3311, 2954, 2930, 2861, 1542, 1461, 1087, $837 \mathrm{~cm}^{-1}$; ${ }^{1} \mathrm{H} \mathrm{NMR}\left(\mathrm{CDCl}_{3}, 400 \mathrm{MHz}\right): \delta 0.12(\mathrm{~s}, 3 \mathrm{H}), 0.14(\mathrm{~d}, J=2 \mathrm{~Hz}, 3 \mathrm{H}), 0.90(\mathrm{~d}, J=1.2 \mathrm{~Hz}, 12 \mathrm{H}), 1.14-1.19$ (m, 1H), 1.26-1.56 (m, 5H), 1.64-1.79 (m, 2H), 2.03 (q, J=6.8 Hz, 2H), 2.38 (t, J=2 Hz, 1H), 4.39$5.01(\mathrm{~m}, \quad 1 \mathrm{H}), \quad 4.92-5.02(\mathrm{~m}, 1 \mathrm{H}), \quad 5.76-5.85 \quad(\mathrm{~m}, 1 \mathrm{H}) ;{ }^{13} \mathrm{C} \quad \mathrm{NMR} \quad\left(\mathrm{CDCl}_{3}, \quad 100 \quad \mathrm{MHz}\right)$ : $\delta-4.96,-4.35,19.46,25.95,26.27,28.87,34.11,36.37,45.94,60.98,72.02,86.30,94.60,114.46,139$. 27; EIMS m/z (\%): 55 (30), 74 (94), 113 (100), 223 (13); HRMS Calcd for $\mathrm{C}_{13} \mathrm{H}_{23} \mathrm{OSi} 223.1518$; Found $223.1517\left[\mathrm{M}-\mathrm{C}_{4} \mathrm{H}_{9}\right]^{+}$.

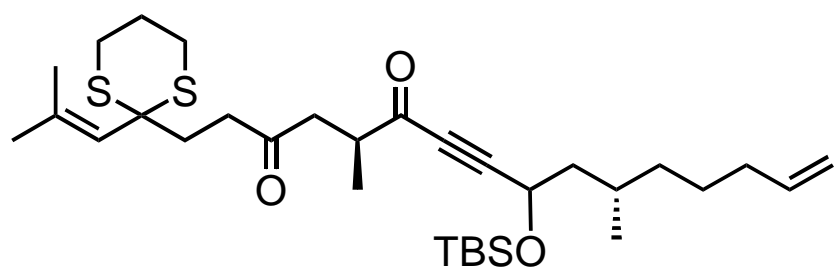

\section{(5S,11S)-9-(tert-Butyldimethylsilyloxy)-5,11-dimethyl-1-(2-(2-methylprop-1-enyl)-1,3-dithian-2-}

yl)hexadec-15-en-7-yne-3,6-dione, 17. To a flame-dried, argon-purged RBF (25mL) was added compound 4 (448 mg, $1.6 \mathrm{mmol})$, and THF ( $3 \mathrm{~mL})$. The solution was cooled to $-78^{\circ} \mathrm{C}$ and $n-\mathrm{BuLi}(0.63$ $\mathrm{mL}, 1.6 \mathrm{mmol})$ was added. The solution was stirred for $20 \mathrm{~min}$ before being transferred to a solution of $12(370 \mathrm{mg}, 1.23 \mathrm{mmol})$ in THF $(3 \mathrm{~mL})$ via cannula. The solution was stirred at $-78{ }^{\circ} \mathrm{C}$ for $3 \mathrm{~h}$ and warmed to $-45^{\circ} \mathrm{C}$ for another $2 \mathrm{~h}$. The reaction was quenched with $\mathrm{NH}_{4} \mathrm{Cl}$ (sat.). The aqueous layer was extracted twice with ether and the combined organic layers were washed with brine, dried over anhydrous $\mathrm{MgSO}_{4}$, filtered, and concentrated via rotary evaporation to give crude corresponding alcohol (650 mg, $\mathrm{R}_{\mathrm{f}}=0.50,20 \%$ ethyl acetate/pet ether). The crude product was diluted with DMSO (10 mL) and sulfur trioxide pyridine complex $(977 \mathrm{mg}, 6.15 \mathrm{mmol})$, TEA $(1.2 \mathrm{~mL}, 8.6 \mathrm{mmol})$ was added. The reaction was stirred for $12 \mathrm{~h}$ at $\mathrm{rt}$ and quenched with $\mathrm{NaHCO}_{3}$ (sat.). The aqueous layer was extracted twice with ether and the combined organic layers were washed with brine, dried over anhydrous $\mathrm{MgSO}_{4}$, 
filtered, and concentrated via rotary evaporation. Flash chromatography on silica gel with pet ether: ethyl acetate $\left(90: 10 ; \mathrm{R}_{f}=0.50\right)$ provided the title compound $(400 \mathrm{mg}, 56.3 \%)$ as a clear oil. IR (neat): 2957, 2928, 2856, 1782, 1734, 1681, 1636, 1257, $836 \mathrm{~cm}^{-1} ;{ }^{1} \mathrm{H}$ NMR $\left(\mathrm{CDCl}_{3}, 400 \mathrm{MHz}\right): \delta 0.11(\mathrm{~s}$, $3 \mathrm{H}), 0.15(\mathrm{~s}, 3 \mathrm{H}), 0.9(\mathrm{~s}, 12 \mathrm{H}), 1.12-1.17(\mathrm{~m}, 1 \mathrm{H}), 1.21(\mathrm{~d}, J=7.2 \mathrm{~Hz}, 3 \mathrm{H}), 1.24-1.48(\mathrm{~m}, 4 \mathrm{H}), 1.56-$ $1.71(\mathrm{~m}, 2 \mathrm{H}), 1.76(\mathrm{~s}, 3 \mathrm{H}), 1.79-1.93(\mathrm{~m}, 2 \mathrm{H}), 1.99(\mathrm{~s}, 3 \mathrm{H}), 2.02(\mathrm{q}, J=6.8 \mathrm{~Hz}, 2 \mathrm{H}), 2.37-2.51(\mathrm{~m}, 3 \mathrm{H})$, 2.59-2.69 (m, 4H), 2.90-3.03 (m, 3H), 3.07-3.11 (m, 1H), 4.54-4.58 (m, 1H), 4.93-5.02 (m, 2H), $5.22(\mathrm{~s}$, $1 \mathrm{H}), 5.75-5.83(\mathrm{~m}, 1 \mathrm{H}) ;{ }^{13} \mathrm{C} \mathrm{NMR}\left(\mathrm{CDCl}_{3}, 100 \mathrm{MHz}\right): \delta-4.96,-4.33,16.34,18.32,19.31,20.08$, 25.11, 25.87, 26.24, 27.64, 27.86, 28.89, 33.81, 34.07, 36.13, 36.76, 39.37, 43.77, 45.01, 51.88, 61.06, 8 2.27, 82.44, 94.76, 114.57, 125.99, 139.09, 141.52, 189.82, 207.75; EIMS m/z (\%): 54 (100), 83 (27), 126 (25), 578 (6); HRMS Calcd for $\mathrm{C}_{32} \mathrm{H}_{54} \mathrm{O}_{3} \mathrm{~S}_{2} \mathrm{Si} 578.3284$; Found $578.3274[\mathrm{M}]^{+}$.

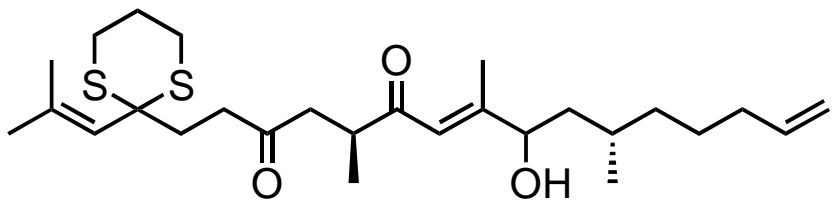

Enone 18. To a flame-dried, argon-purged RBF $(10 \mathrm{~mL})$ was added $\mathrm{CuCN}(25 \mathrm{mg}, 0.27 \mathrm{mmol}), \mathrm{LiCl}$ $(11.6 \mathrm{mg}, 0.27 \mathrm{mmol})$, and $\mathrm{Et}_{2} \mathrm{O}(0.3 \mathrm{~mL})$. The suspension was cooled to $-78{ }^{\circ} \mathrm{C}$ and $\mathrm{MeLi}(0.35 \mathrm{~mL}$, $0.54 \mathrm{mmol}$ ) was added. The solution was allowed to warm to $-30{ }^{\circ} \mathrm{C}$ to give a homogeneous solution and then cooled back to $-78^{\circ} \mathrm{C}$. The cuprate solution was transferred to the solution of ynone $17(130 \mathrm{mg}$, $0.223 \mathrm{mmol})$ in $\mathrm{Et}_{2} \mathrm{O}(0.2 \mathrm{~mL})$ via cannula at $-78^{\circ} \mathrm{C}$ and let it stir for $90 \mathrm{~min}$ before quenched by $\mathrm{MeOH}$ $(0.2 \mathrm{~mL})$ at $-78^{\circ} \mathrm{C}$. The mixture was warmed to $\mathrm{rt}$ and $\mathrm{NH}_{4} \mathrm{OH} / \mathrm{NH}_{4} \mathrm{Cl}(9: 1)$ was added. The aqueous layer was extracted twice with ether and the combined organic layers were washed with brine, dried over anhydrous $\mathrm{MgSO}_{4}$, filtered, and concentrated via rotary evaporation. Flash chromatography on silica gel with pet ether: ethyl acetate $\left(90: 10 ; \mathrm{R}_{f}=0.60\right)$ provided the compound $(100 \mathrm{mg}, 75 \%)$ as a clear oil. To a RBF $(10 \mathrm{~mL})$ was added the above compound $(100 \mathrm{mg}, 0.168 \mathrm{mmol})$ and THF $(0.3 \mathrm{~mL})$. TBAF $(0.3$ $\mathrm{mL}, 0.3 \mathrm{mmol}$ ) was added and stirred at $\mathrm{rt}$ for $1 \mathrm{~h}$ and quenched by $\mathrm{NaHCO}_{3}$ (sat.). The aqueous layer was extracted twice with ether and the combined organic layers were washed with brine, dried over anhydrous $\mathrm{MgSO}_{4}$, filtered, and concentrated via rotary evaporation. Flash chromatography on silica gel with pet ether: ethyl acetate $\left(80: 20 ; \mathrm{R}_{f}=0.30\right)$ provided the title compound $(42 \mathrm{mg}, 52 \%)$ as a clear oil. IR (neat): 3461 (br), 2928, 1710, 1684, 1619, 1550, 1375, 867 $\mathrm{cm}^{-1} ;{ }^{1} \mathrm{H} \mathrm{NMR}\left(\mathrm{CD}_{2} \mathrm{Cl}_{2}, 400 \mathrm{MHz}\right): \delta 0.92$ $(\mathrm{d}, J=6.4 \mathrm{~Hz}, 3 \mathrm{H}), 1.13-1.88(\mathrm{~m}, 7 \mathrm{H}), 1.06(\mathrm{~d}, J=6.8 \mathrm{~Hz}, 3 \mathrm{H}), 1.75(\mathrm{~s}, 3 \mathrm{H}), 1.81-1.92(\mathrm{~m}, 2 \mathrm{H}), 1.97(\mathrm{~s}$, $3 \mathrm{H}), 2.01(\mathrm{~s}, 5 \mathrm{H}), 2.30-2.43(\mathrm{~m}, 3 \mathrm{H}), 2.57-2.69(\mathrm{~m}, 5 \mathrm{H}), 2.88-2.97(\mathrm{~m}, 3 \mathrm{H}), 3.00-3.08(\mathrm{~m}, 1 \mathrm{H}), 4.13-$ $4.16(\mathrm{~m}, 1 \mathrm{H}), 4.91-5.02(\mathrm{~m}, 2 \mathrm{H}), 5.24(\mathrm{~s}, 1 \mathrm{H}), 5.77-5.87(\mathrm{~m}, 1 \mathrm{H}), 6.35-6.42(\mathrm{~m}, 1 \mathrm{H}) ;{ }^{13} \mathrm{C} \mathrm{NMR}\left(\mathrm{CDCl}_{3}\right.$, $100 \mathrm{MHz}): \delta 17.02,19.19,20.23,20.95,25.12,26.22,27.61,27.84,29.54,33.84,34.15,35.75,37.30$, 39.27, 42.35, 43.03, 45.95, 51.95, 74.73, 114.58, 120.57, 126.07, 139.13, 141.31, 160.04, 203.68, 208.94 ; EIMS m/z (\%): 43 (42), 69 (45), 173 (100), 220 (49), 480 (6); HRMS Calcd for $\mathrm{C}_{27} \mathrm{H}_{44} \mathrm{O}_{3} \mathrm{~S}_{2} 480.2732$; Found $480.2751[\mathrm{M}]^{+}$.

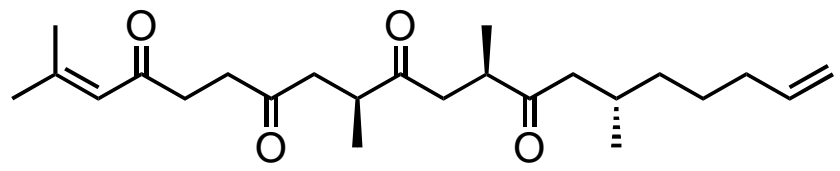

9-epi-Amphidinoketide I, 19. To a flame-dried, argon-purged RBF (10 mL) was added $\mathrm{CuCl}(2 \mathrm{mg}$, $0.02 \mathrm{mmol}), \mathrm{NaO}-t-\mathrm{Bu}(1.9 \mathrm{mg}, 0.02 \mathrm{mmol}),(R, S)-\mathrm{PPF}-\mathrm{P}(t-\mathrm{Bu})_{2}(5.4 \mathrm{mg}, 0.01 \mathrm{mmol})$ and THF $(0.3$ $\mathrm{mL})$. The solution was cooled to $0{ }^{\circ} \mathrm{C}$ and stirred for $30 \mathrm{~min}$. PMHS (13 $\left.\mu \mathrm{L}, 0.2 \mathrm{mmol}\right)$ was added and the solution was allowed to stir for another $5 \mathrm{~min}$ before cooled to $-20^{\circ} \mathrm{C}$. Enone $18(40 \mathrm{mg}, 0.83 \mathrm{mmol})$ 
was diluted with THF $(0.1 \mathrm{~mL})$ and then transferred to the $\mathrm{CuH}$ solution at $-20{ }^{\circ} \mathrm{C}$. The reaction was stirred until complete (monitored by $\mathrm{TLC}, \mathrm{R}_{\mathrm{f}}=0.40,20 \%$ ethyl acetate/pet ether, $3 \mathrm{~h}$ ). Then, the reaction was quenched by $\mathrm{NaHCO}_{3}$ (sat.) and ether, and stirred for $1 \mathrm{~h}$ at $\mathrm{rt}$. The aqueous layer was extracted twice with ether and the combined organic layers were washed with brine, dried over anhydrous $\mathrm{MgSO}_{4}$, filtered, and concentrated via rotary evaporation to give crude product (39 mg). The crude product was diluted with $\mathrm{CH}_{2} \mathrm{Cl}_{2}(2 \mathrm{~mL})$. TPAP $(3.5 \mathrm{mg}, 0.01 \mathrm{mmol})$, NMO (23 mg, $\left.0.2 \mathrm{mmol}\right)$, and $4 \AA \AA \mathrm{MS}$ was added. The mixture was allowed to stir at $\mathrm{rt}$ for $1 \mathrm{~h}$ and then filtered through Celite, and the filter cake was further rinsed with $\mathrm{Et}_{2} \mathrm{O}$. The combined organic layers were concentrated via rotary evaporation. Flash chromatography on silica gel with pet ether:ethyl acetate $\left(80: 20 ; \mathrm{R}_{f}=0.50\right)$ provided the 1,4-adduct $(10 \mathrm{mg}, 25 \%)$ as a clear oil. To a RBF $(25 \mathrm{~mL})$ was added the above compound (10 $\mathrm{mg}$, $0.02 \mathrm{mmol}), \mathrm{HgCl}_{2}(10.8 \mathrm{mg}, 0.04 \mathrm{mmol}), \mathrm{CaCO}_{3}(4 \mathrm{mg}, 0.04 \mathrm{mmol})$, and THF $(0.5 \mathrm{~mL})$. The reaction was stirred at $\mathrm{rt}$ for $1 \mathrm{~h}$ and then quenched by $\mathrm{Na}_{2} \mathrm{~S}$ (sat.). The aqueous layer was extracted twice with ether and the combined organic layers were washed with brine, dried over anhydrous $\mathrm{MgSO}_{4}$, filtered, and concentrated via rotary evaporation. Flash chromatography on silica gel with pet ether: ethyl acetate $\left(80: 20 ; \mathrm{R}_{f}=0.30\right)$ provided the title compound $(7 \mathrm{mg}, 86 \%)$ as a clear oil. $[\alpha]^{20}{ }_{\mathrm{D}}+1\left(\mathrm{c} 0.5, \mathrm{CH}_{2} \mathrm{Cl}_{2}\right) ; \mathrm{IR}$ (neat): 2959, 2925, 1709, 1685, 1621, 1553, 1458, $910 \mathrm{~cm}^{-1} ;{ }^{1} \mathrm{H} \mathrm{NMR}\left(\mathrm{CD}_{2} \mathrm{Cl}_{2}, 500 \mathrm{MHz}\right): \delta 0.86(\mathrm{~d}, J$ $=7 \mathrm{~Hz}, 3 \mathrm{H}), 1.03(\mathrm{~d}, J=7.0 \mathrm{~Hz}, 3 \mathrm{H}), 1.06(\mathrm{~d}, J=6.0 \mathrm{~Hz}, 3 \mathrm{H}), 1.06-1.42(\mathrm{~m}, 4 \mathrm{H}), 1.87(\mathrm{~s}, 3 \mathrm{H}), 1.96-$ $2.05(\mathrm{~m}, 3 \mathrm{H}), 2.09(\mathrm{~s}, 3 \mathrm{H}), 2.33(\mathrm{dd}, J=17,7.5 \mathrm{~Hz}, 1 \mathrm{H}), 2.44-2.52(\mathrm{~m}, 3 \mathrm{H}), 2.58-2.74(\mathrm{~m}, 4 \mathrm{H}), 2.88-$ $2.99(\mathrm{~m}, 4 \mathrm{H}), 4.91-5.08(\mathrm{~m}, 2 \mathrm{H}), 5.79-5.84(\mathrm{~m}, 1 \mathrm{H}), 6.09(\mathrm{t}, J=1 \mathrm{~Hz}, 1 \mathrm{H}) ;{ }^{13} \mathrm{C} \mathrm{NMR}\left(\mathrm{CD}_{2} \mathrm{Cl}_{2}, 125\right.$ $\mathrm{MHz}): \quad \delta 16.77,16.88,20.05,20.92,26.88,27.86,29.03,34.47,36.70,36.85,38.05,41.57,41.97,44.2$ 2, 45.85, 48.88, 114.49, 123.85, 139.69, 155.64, 199.09, 208.37, 212.08, 213.24; EIMS m/z (\%): 55 (33), 205 (100), 219 (50), 373 (72) ; HRMS Calcd for $\mathrm{C}_{24} \mathrm{H}_{39} \mathrm{O}_{4} 391.2843$; Found $391.2843[\mathrm{M}+\mathrm{H}]^{+}$. The ee was determined on a Daicel Chiralcel OD-R column $\left(2.5 \% \mathrm{IPA} / \mathrm{hexane}, 0.5 \mathrm{~mL} / \mathrm{min}, \mathrm{R}_{\mathrm{t}}=37.55 \mathrm{~min}\right.$ and 39.63 min (major)): $88.74 \%$. 


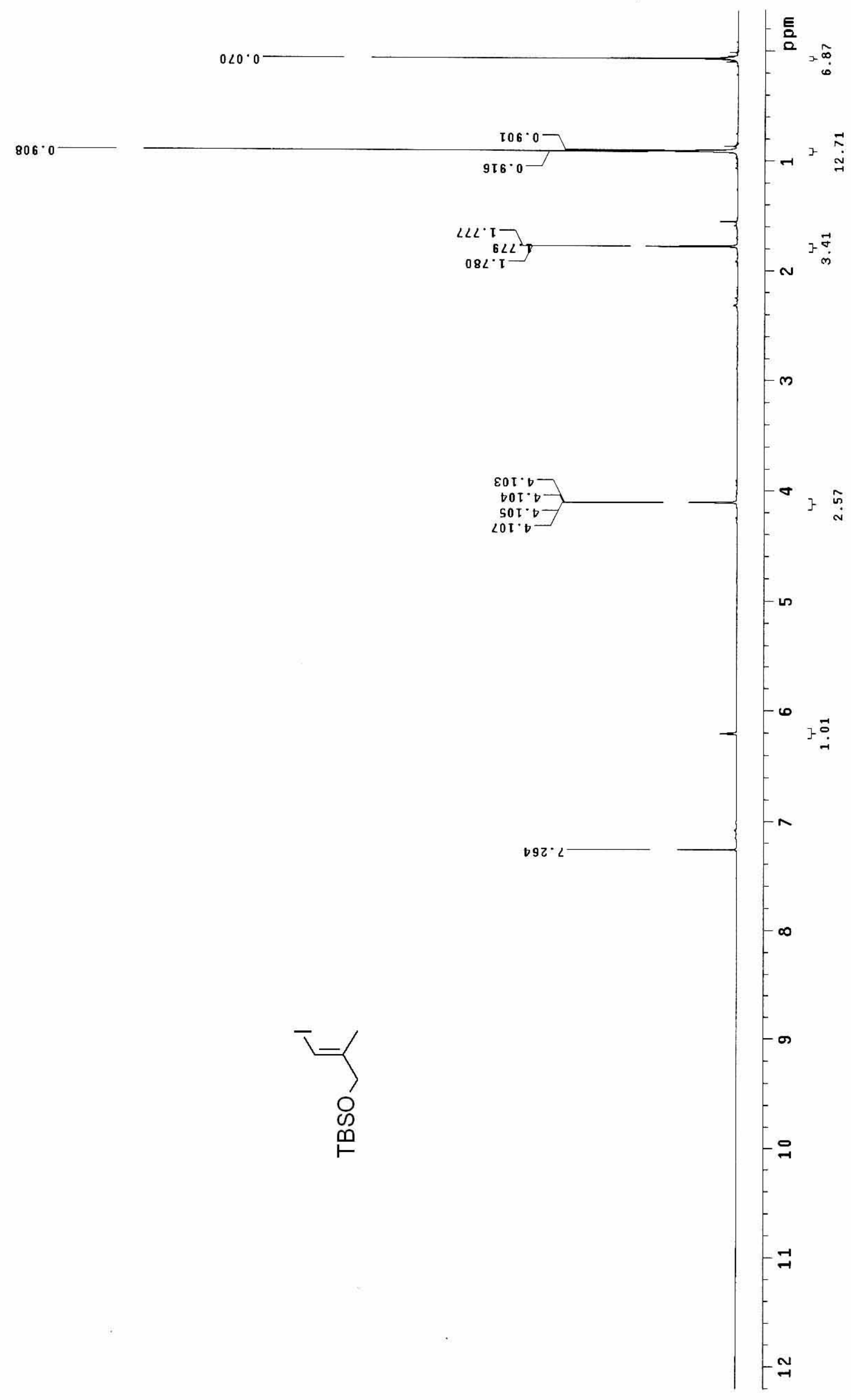




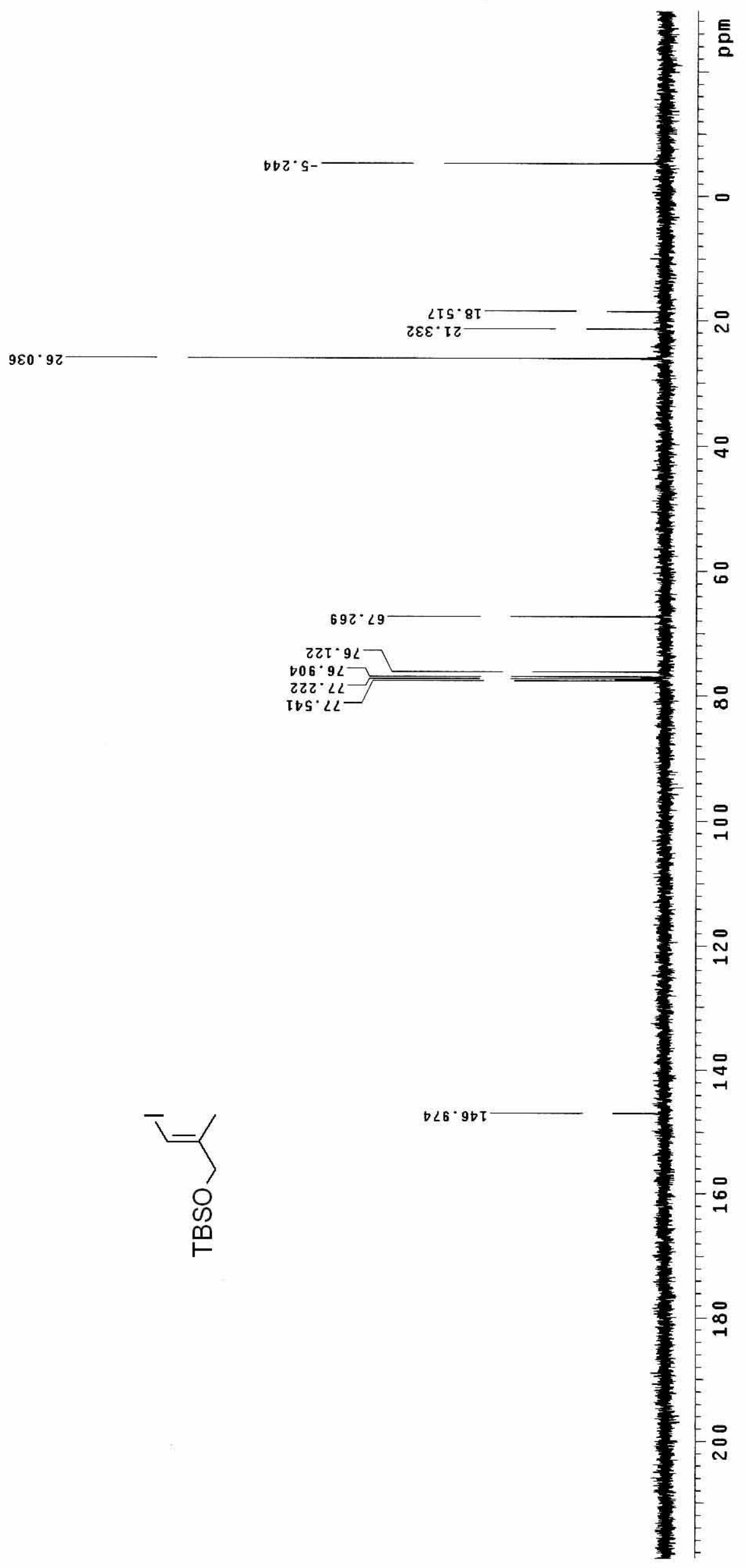

S-11 


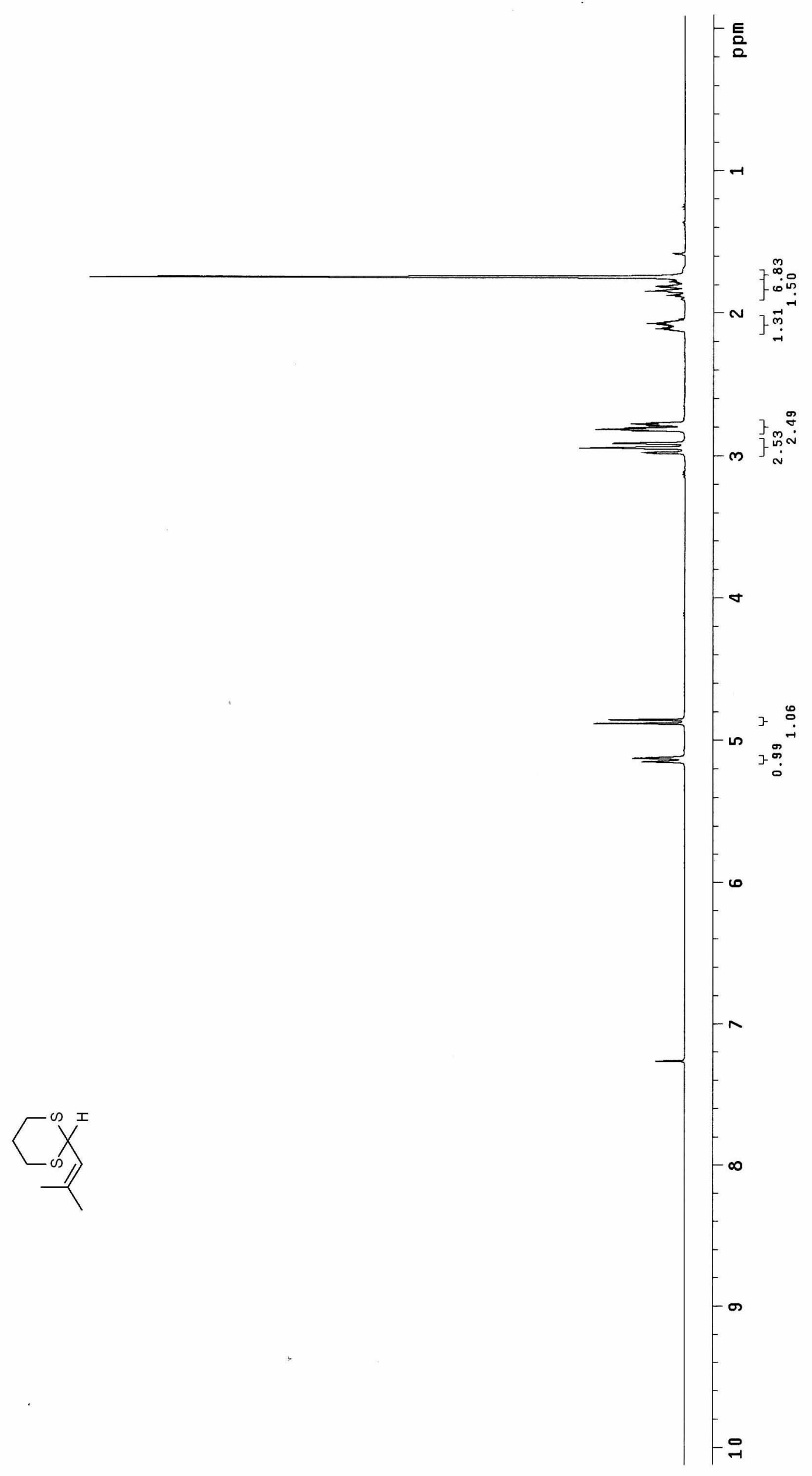

S-12 


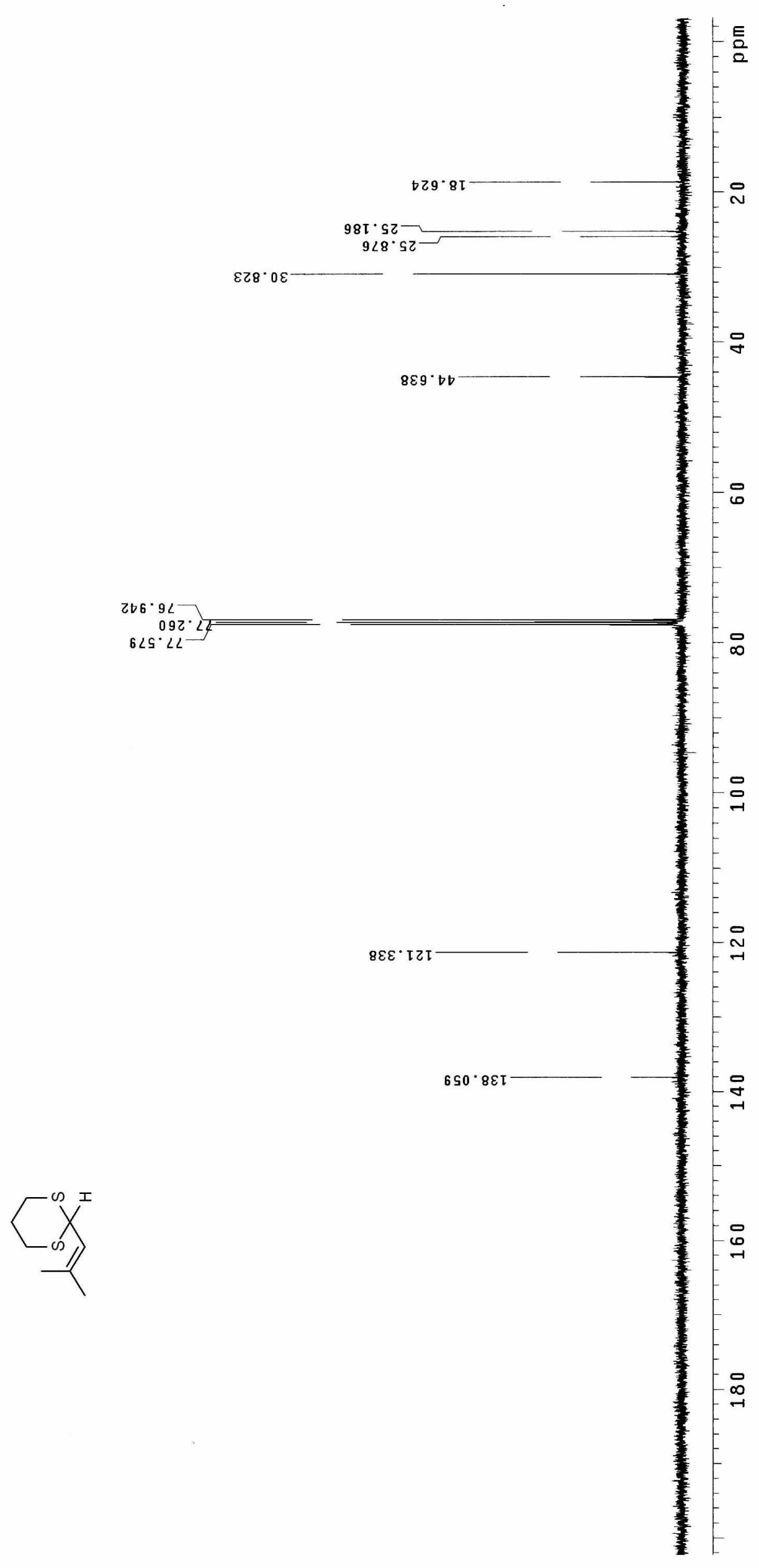

S-13 


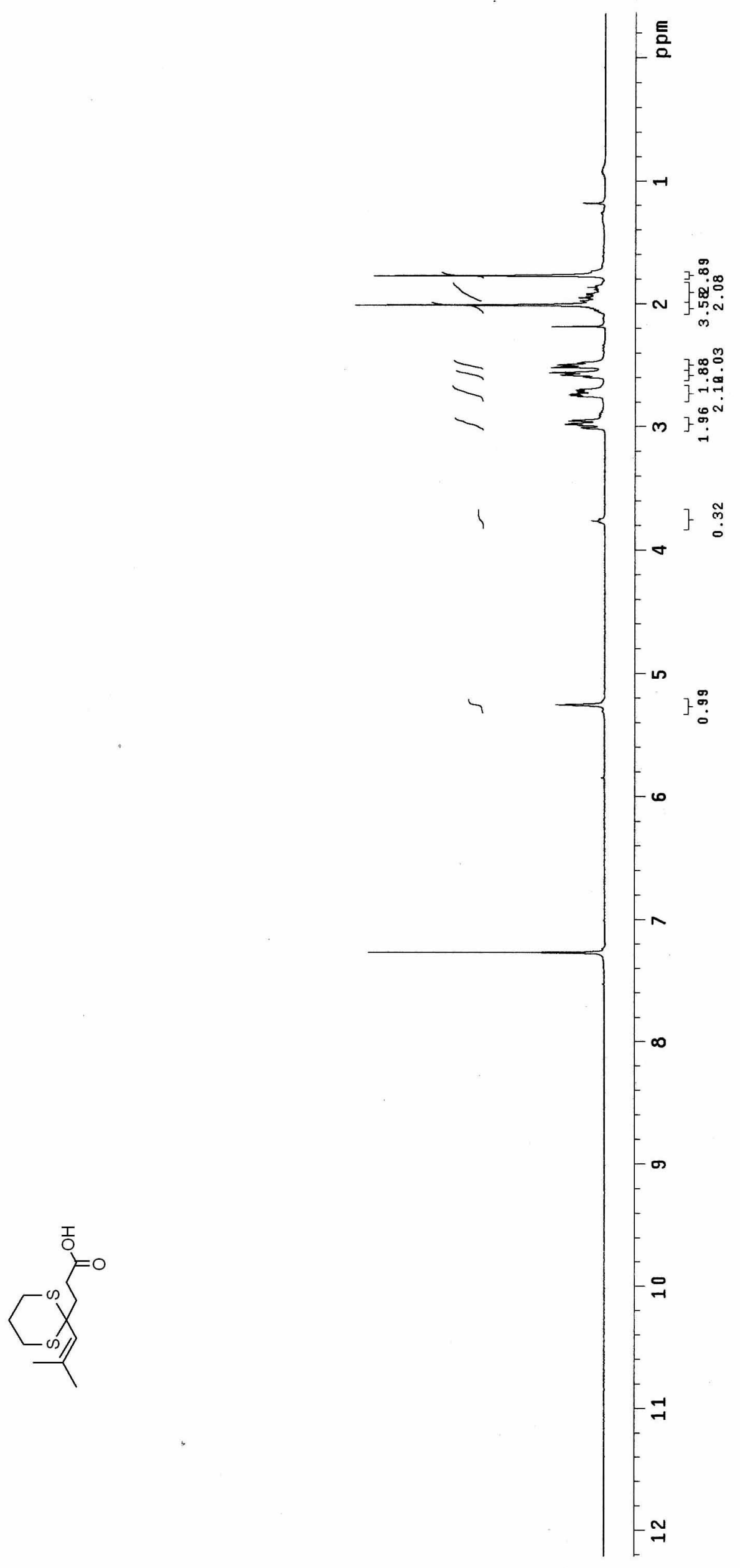

S-14 


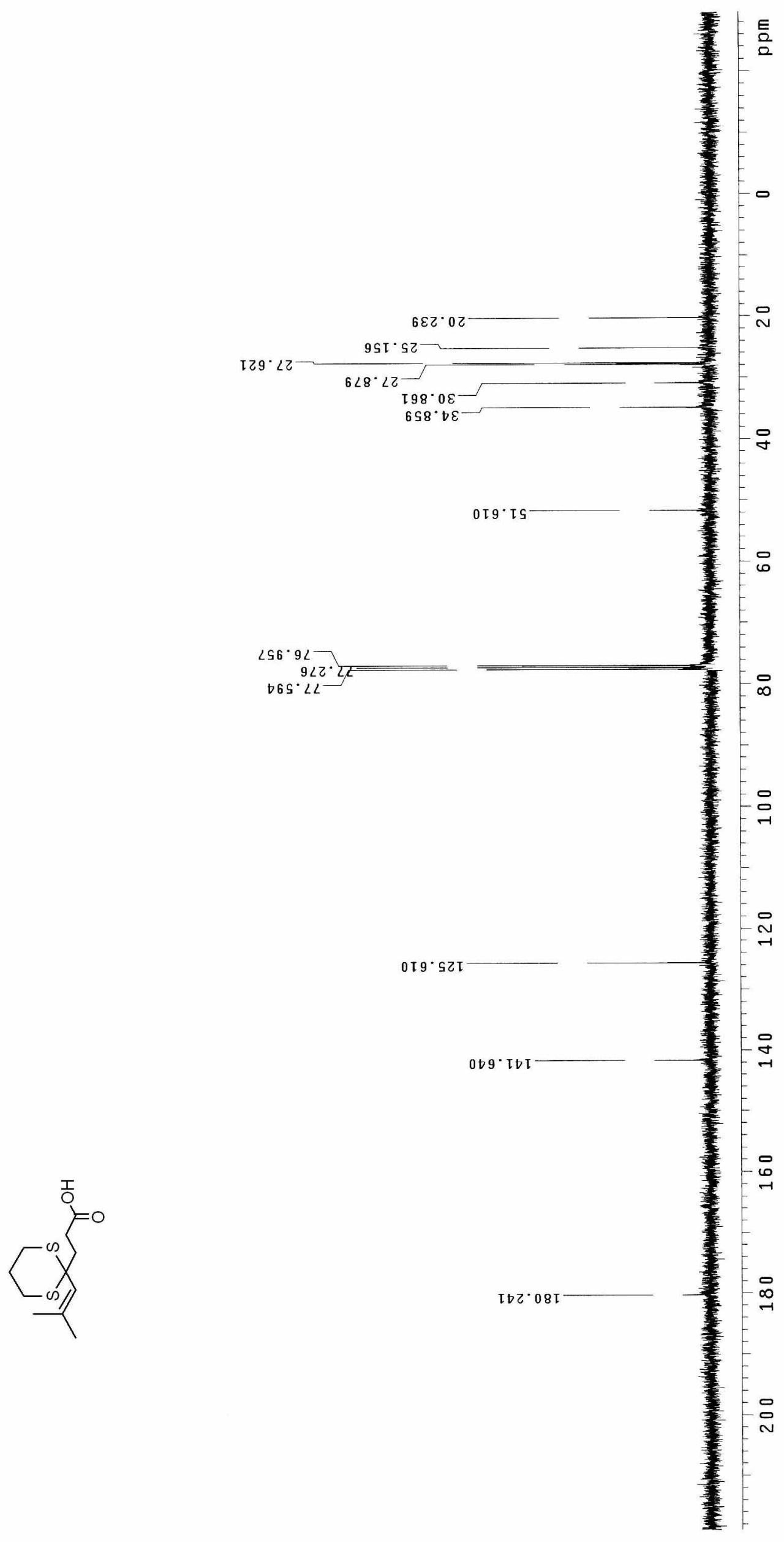

S-15 


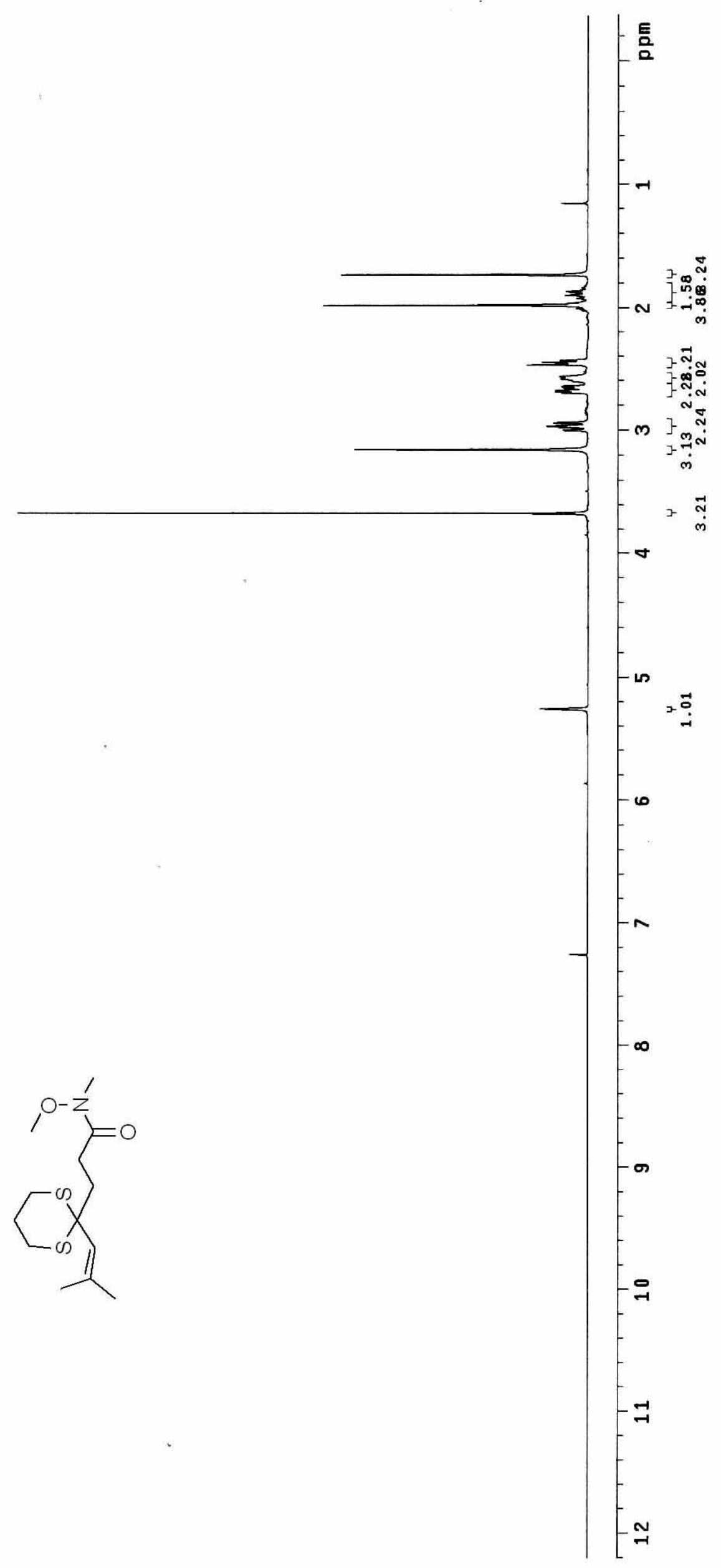

S-16 


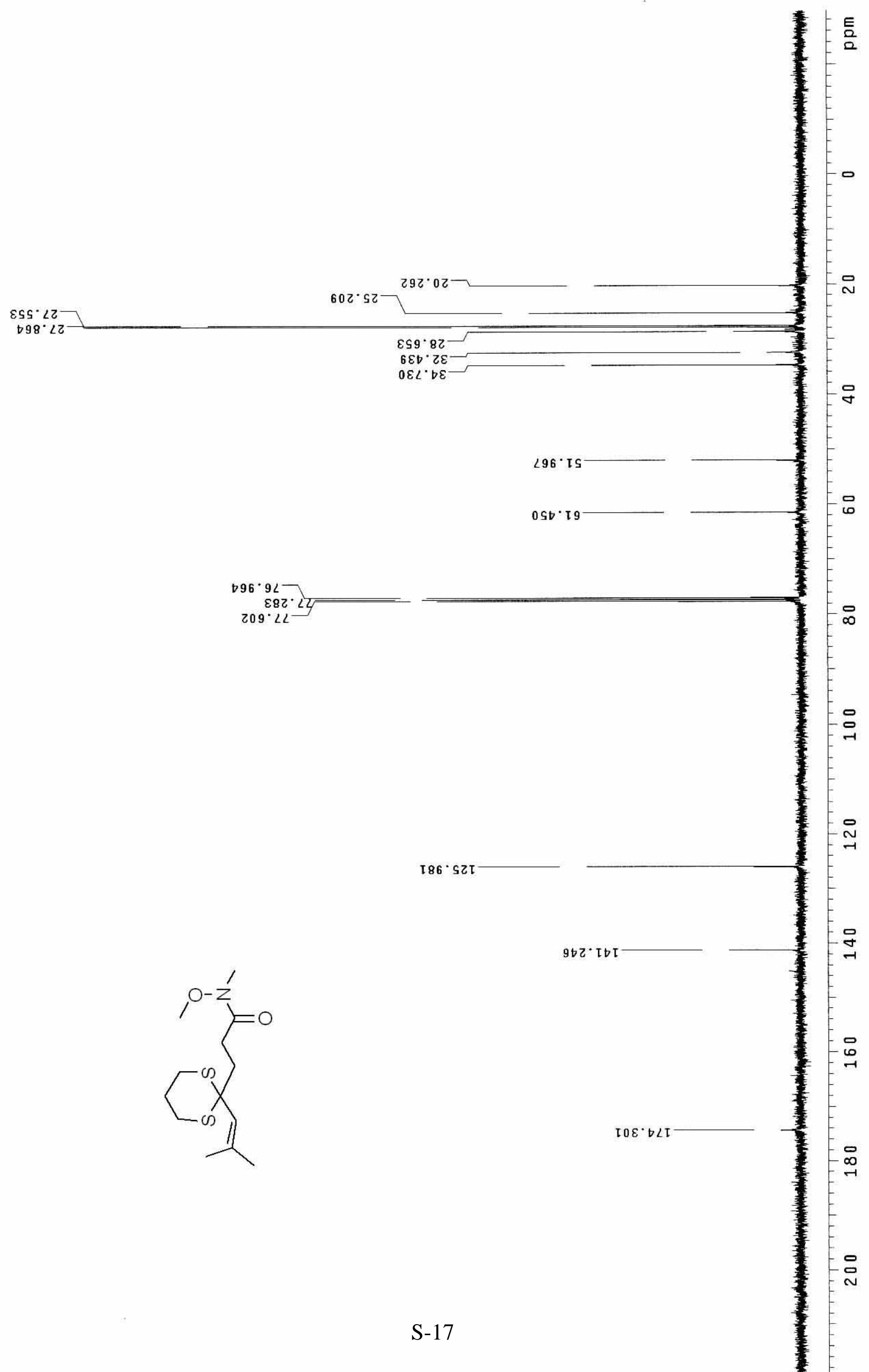




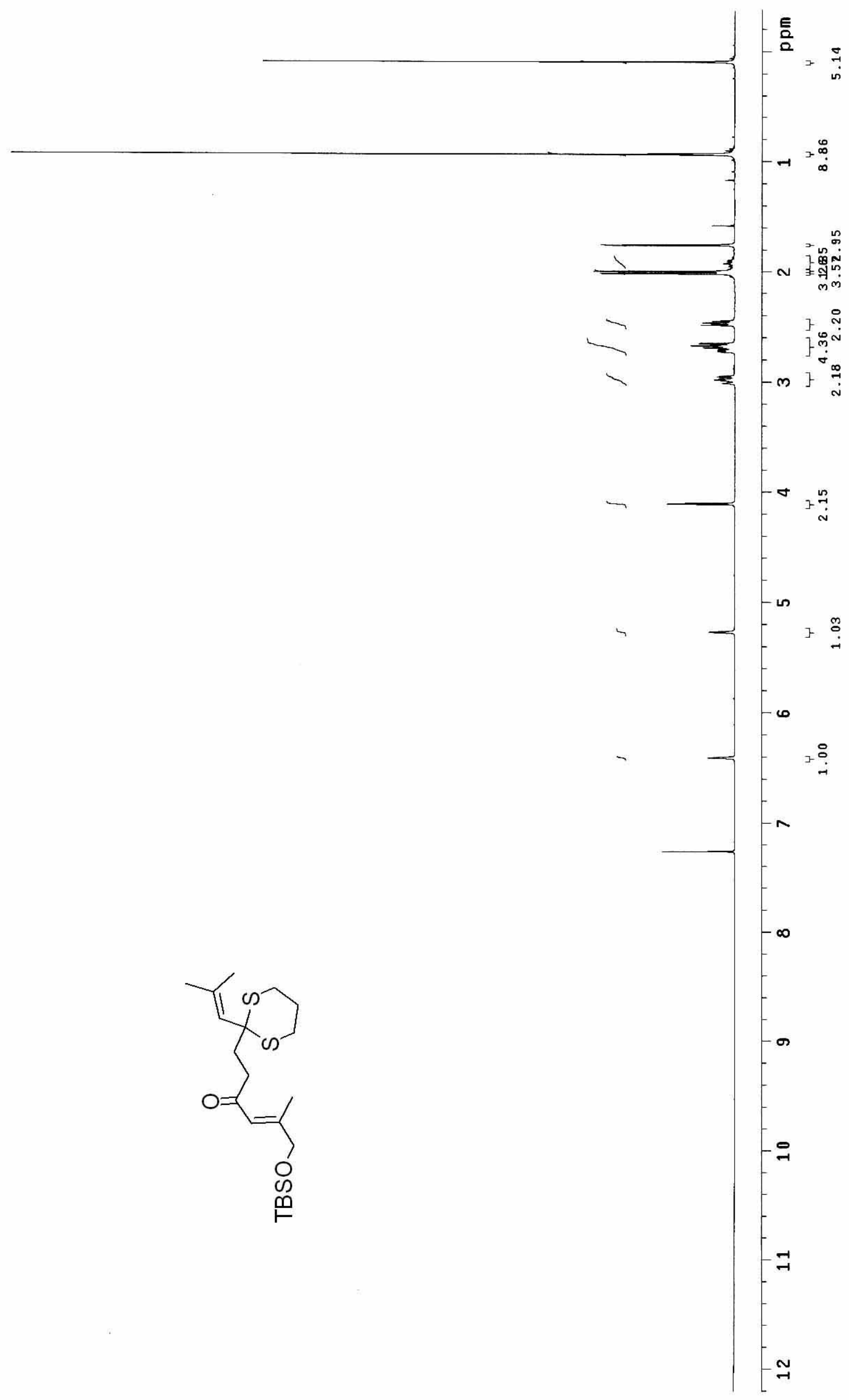




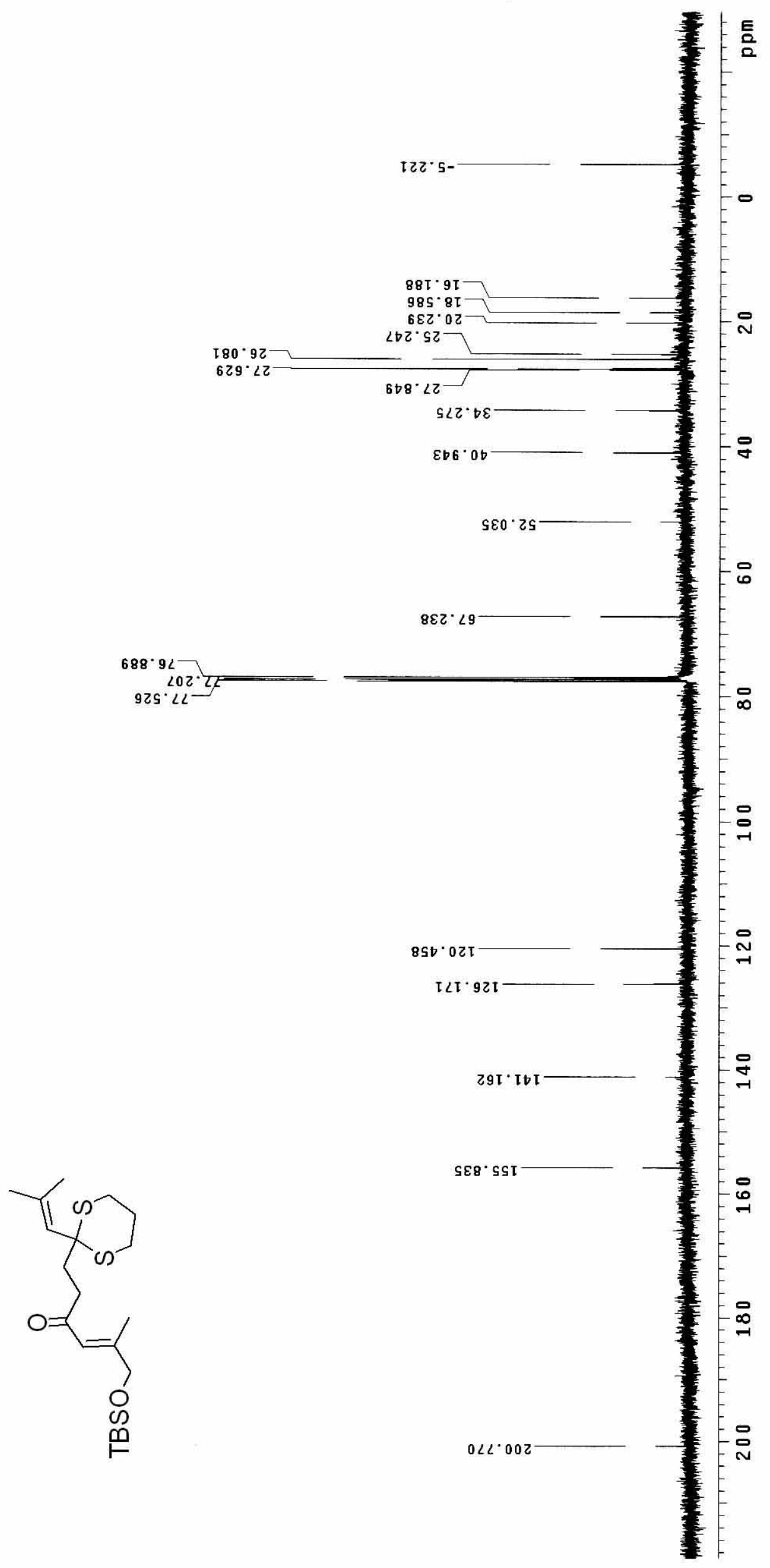




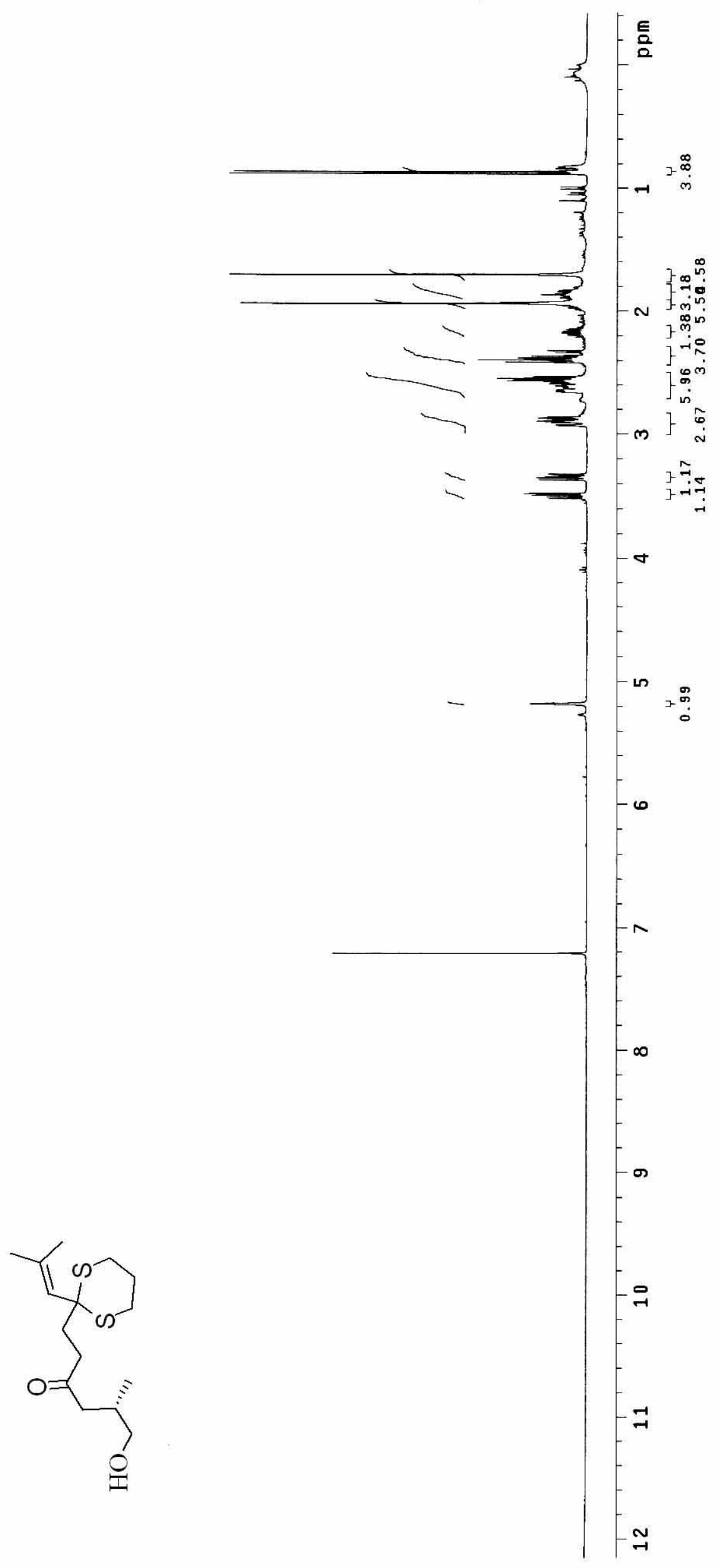




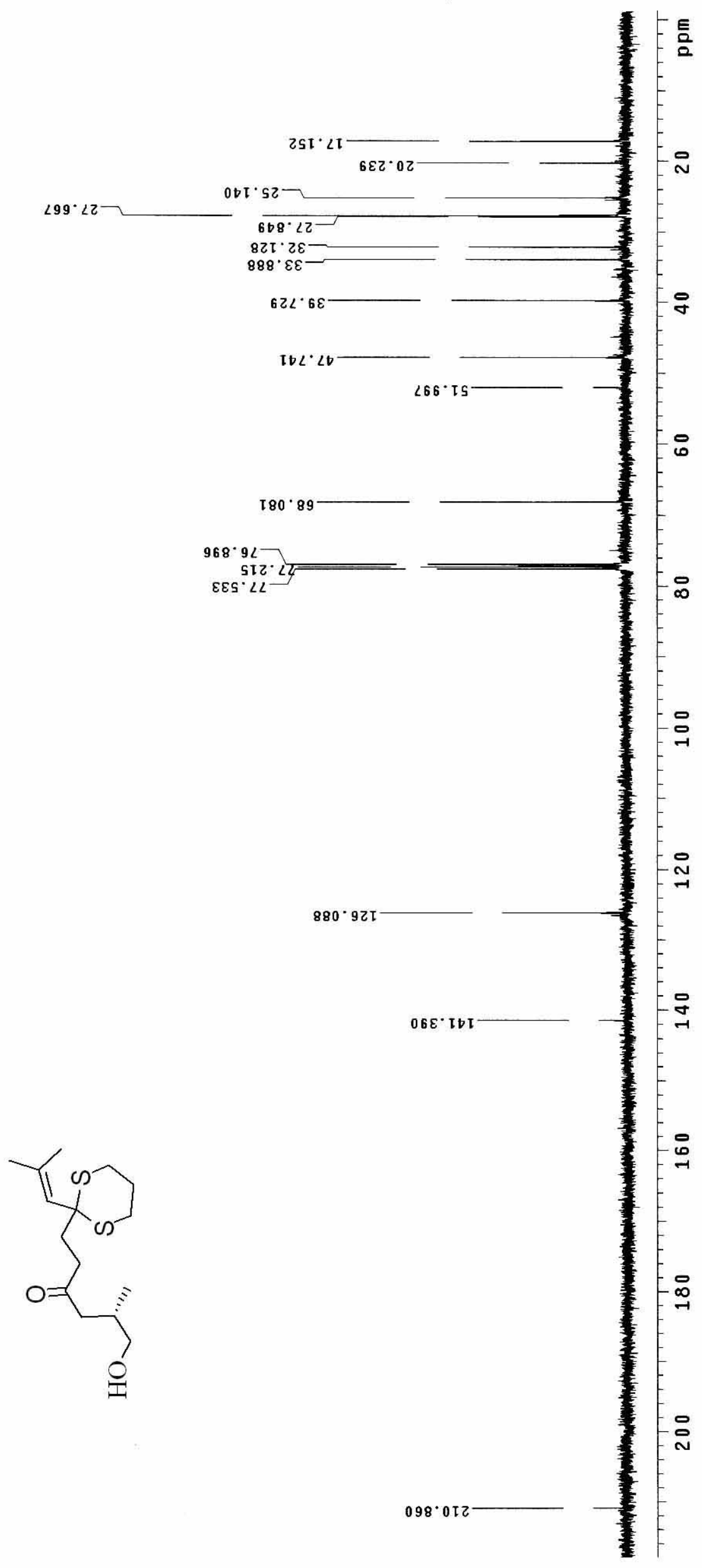




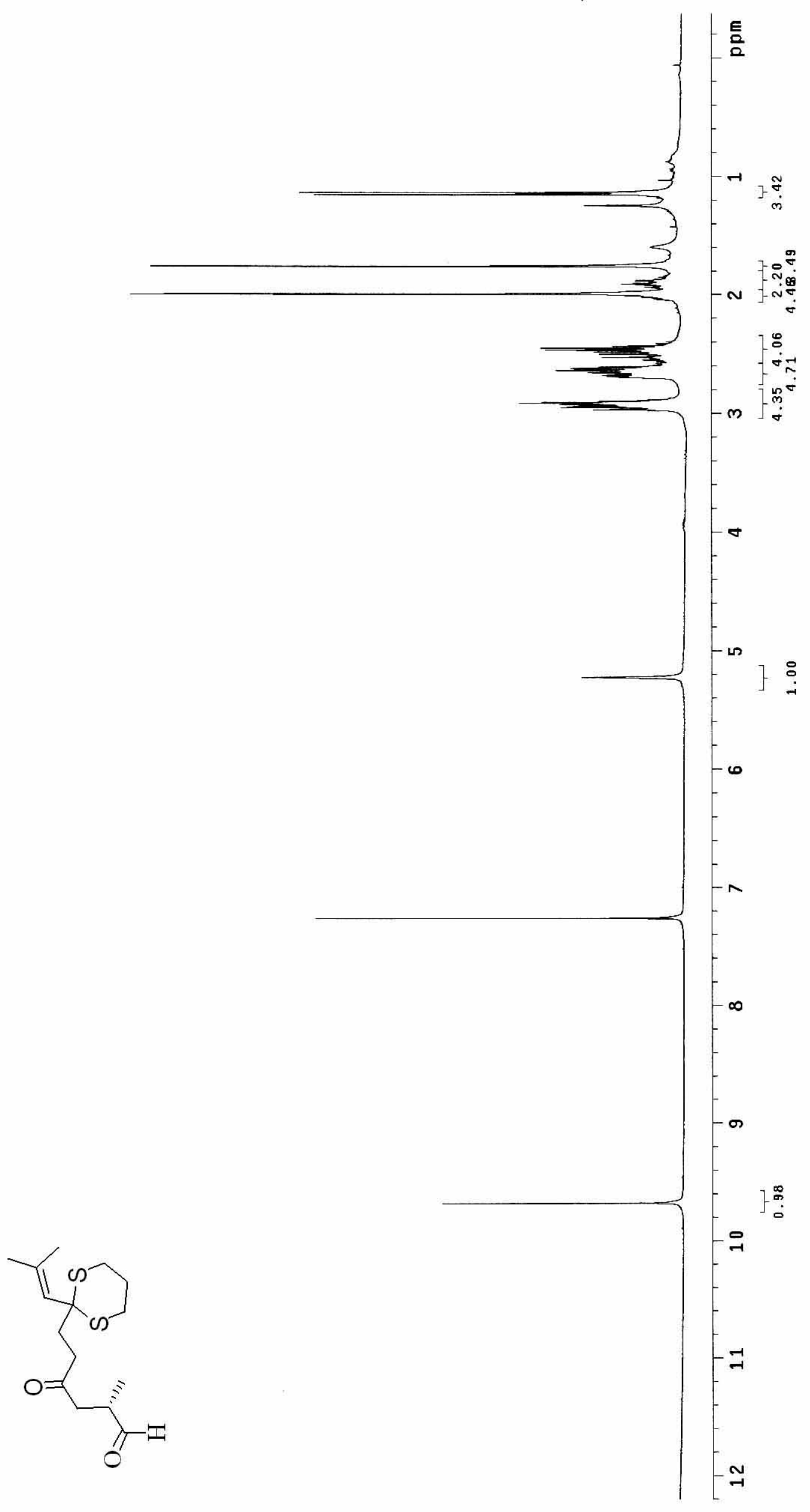




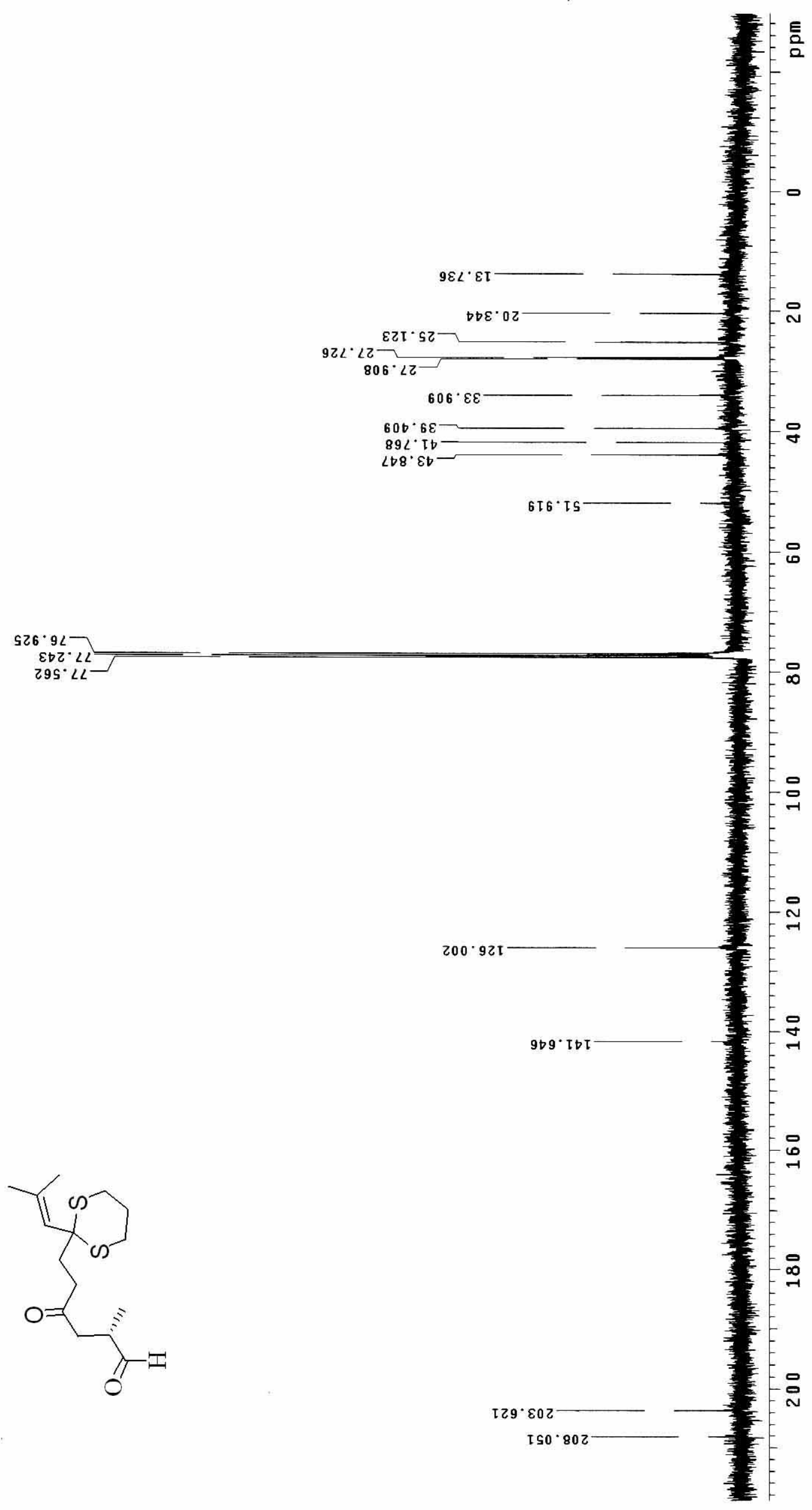




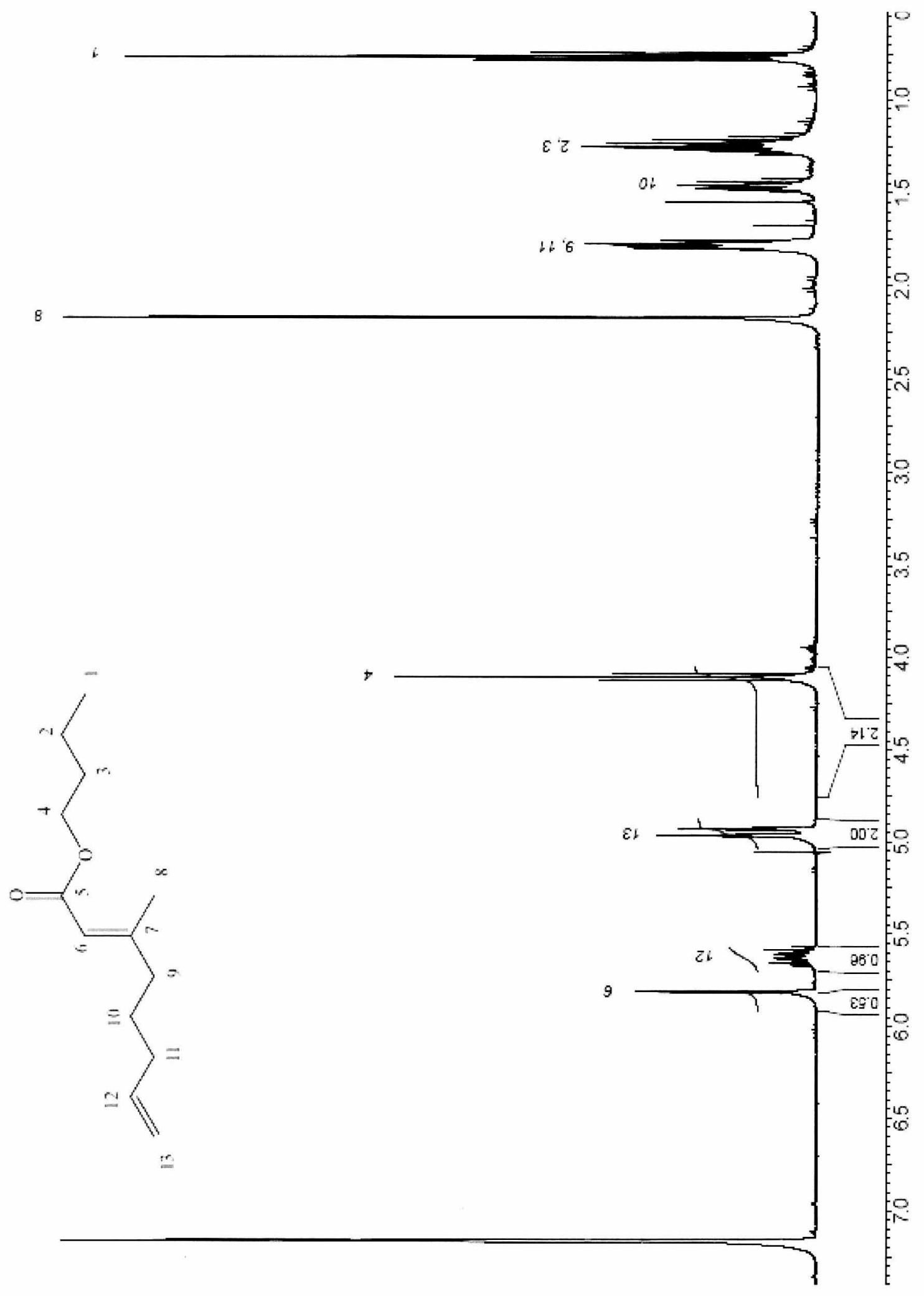




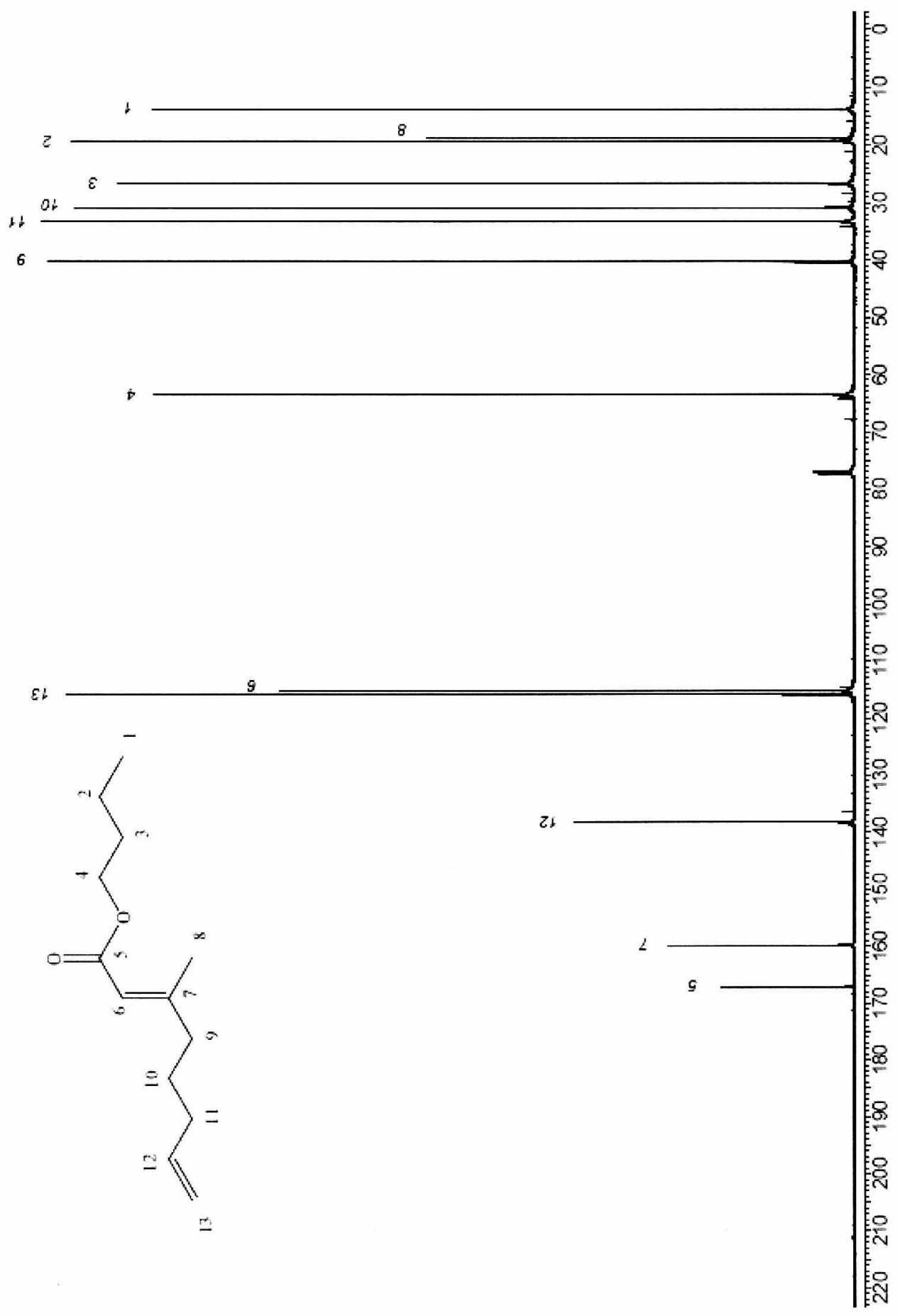

S-25 


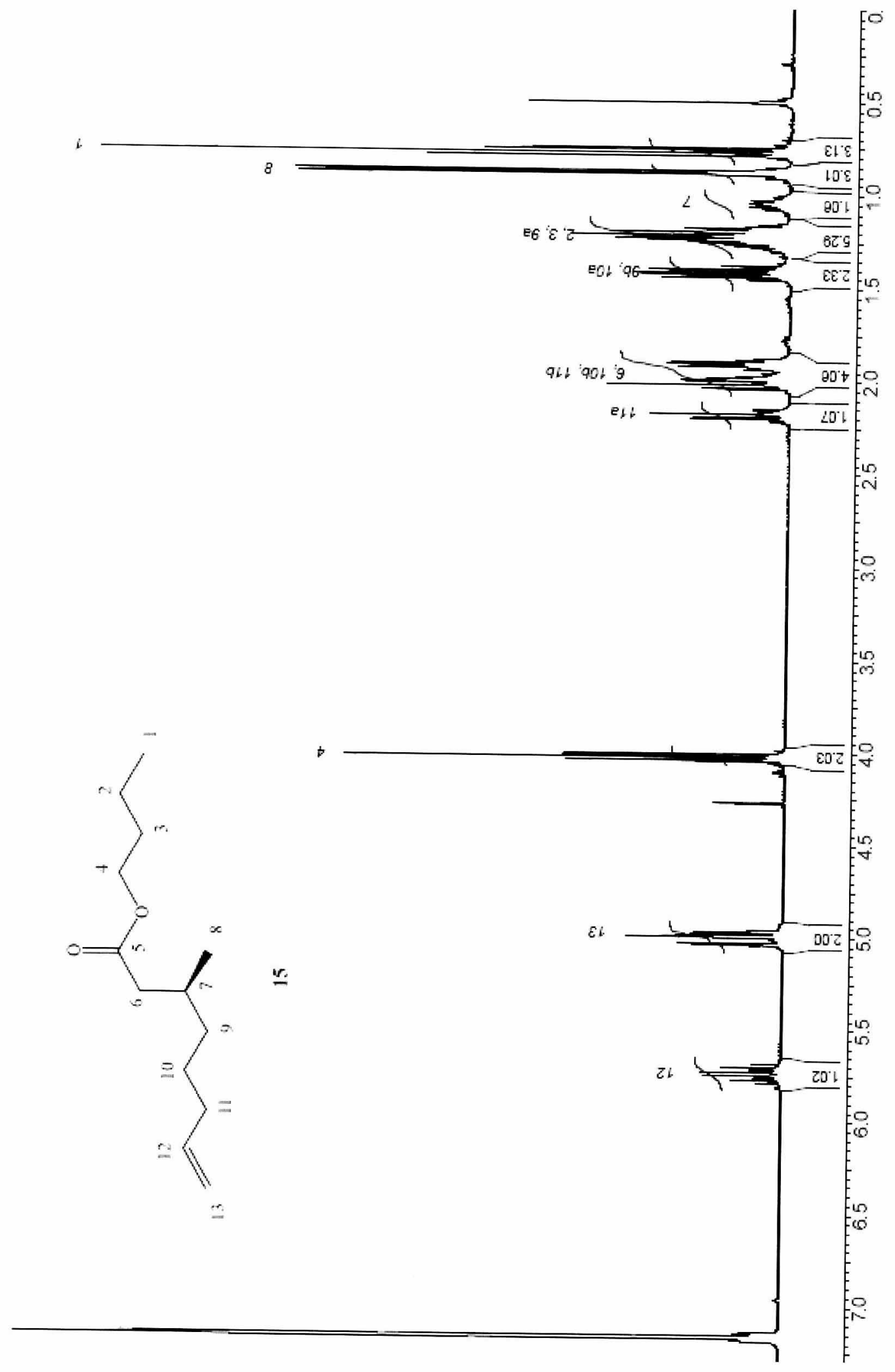




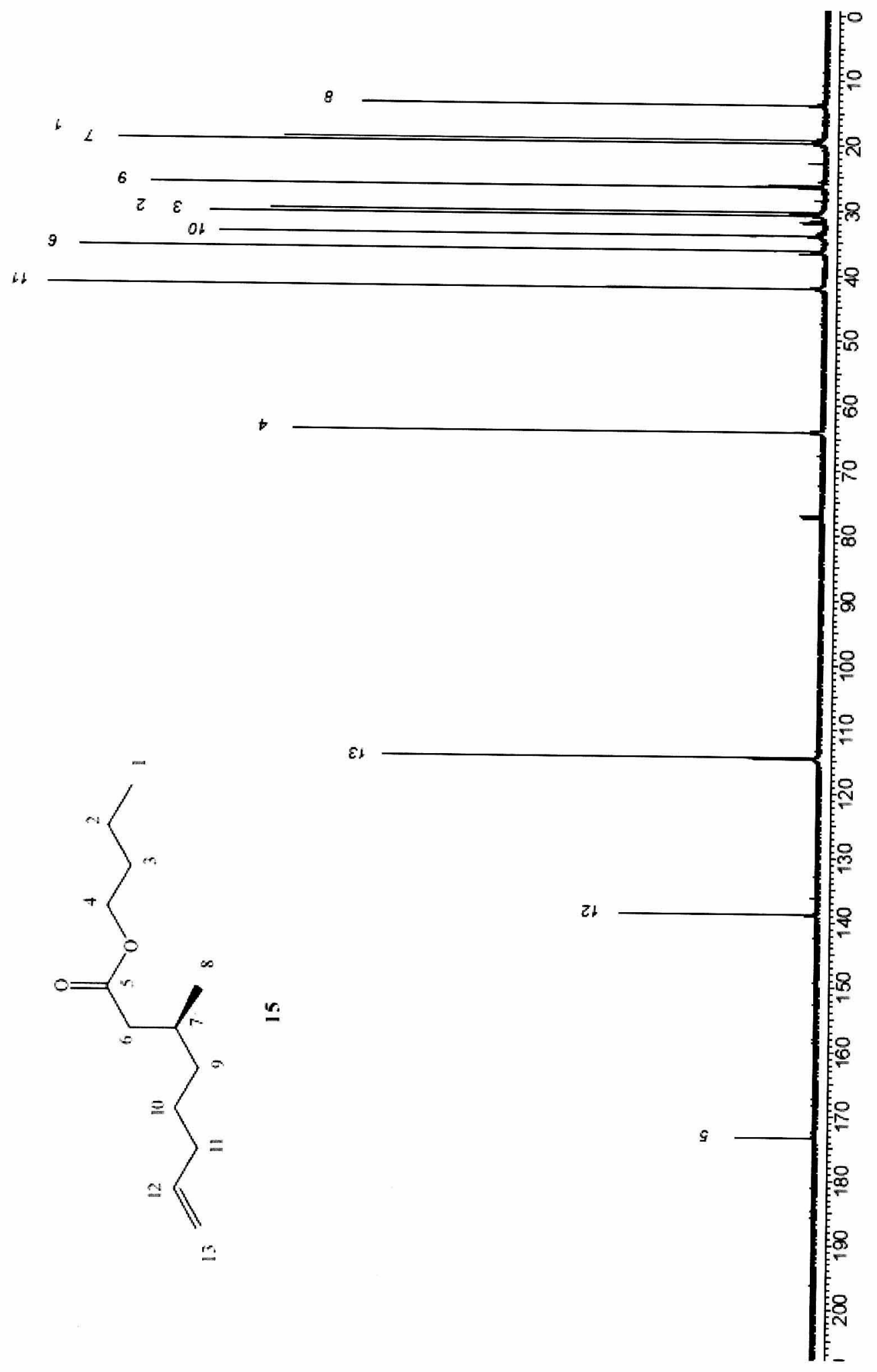

S-27 


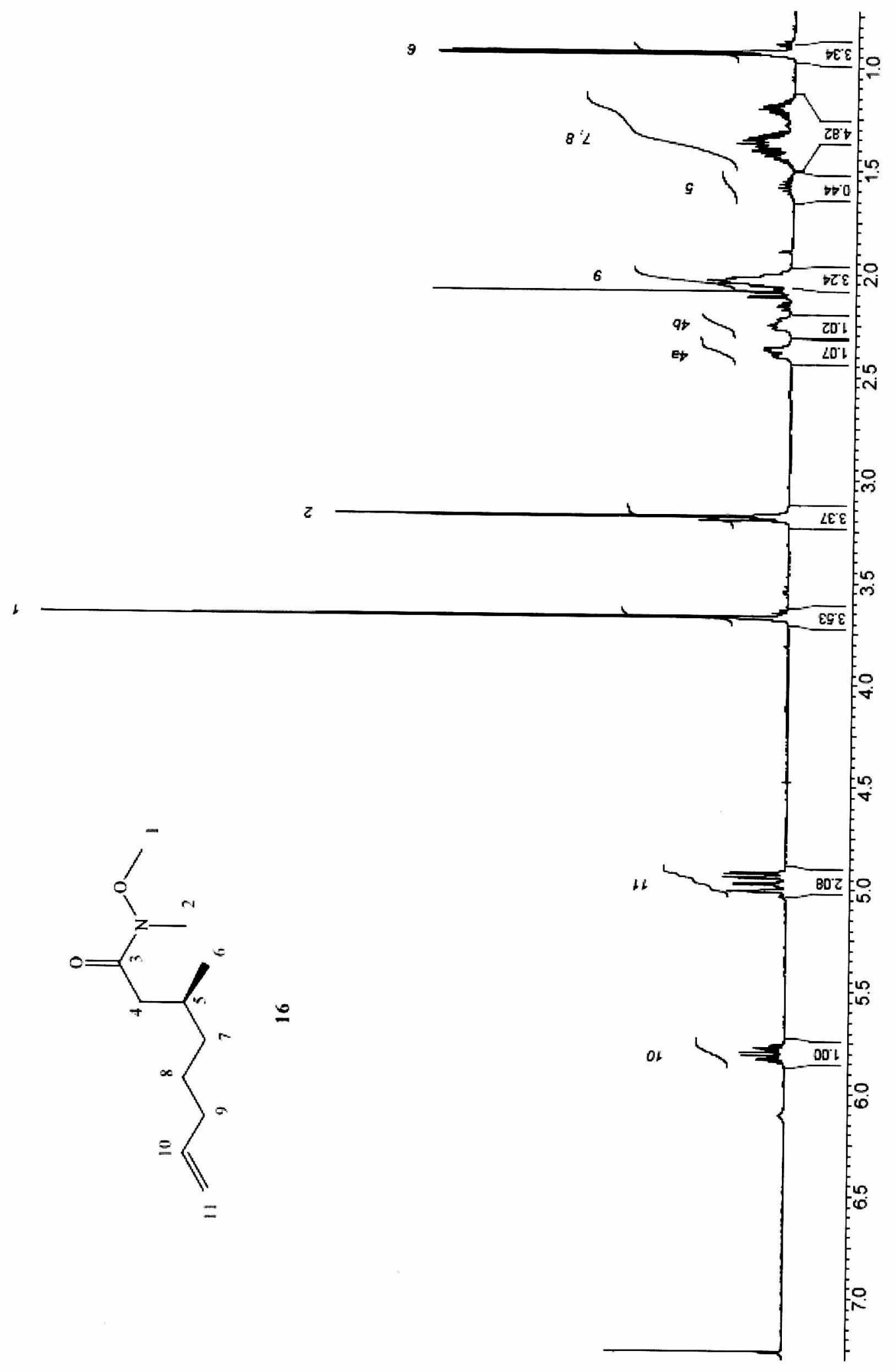




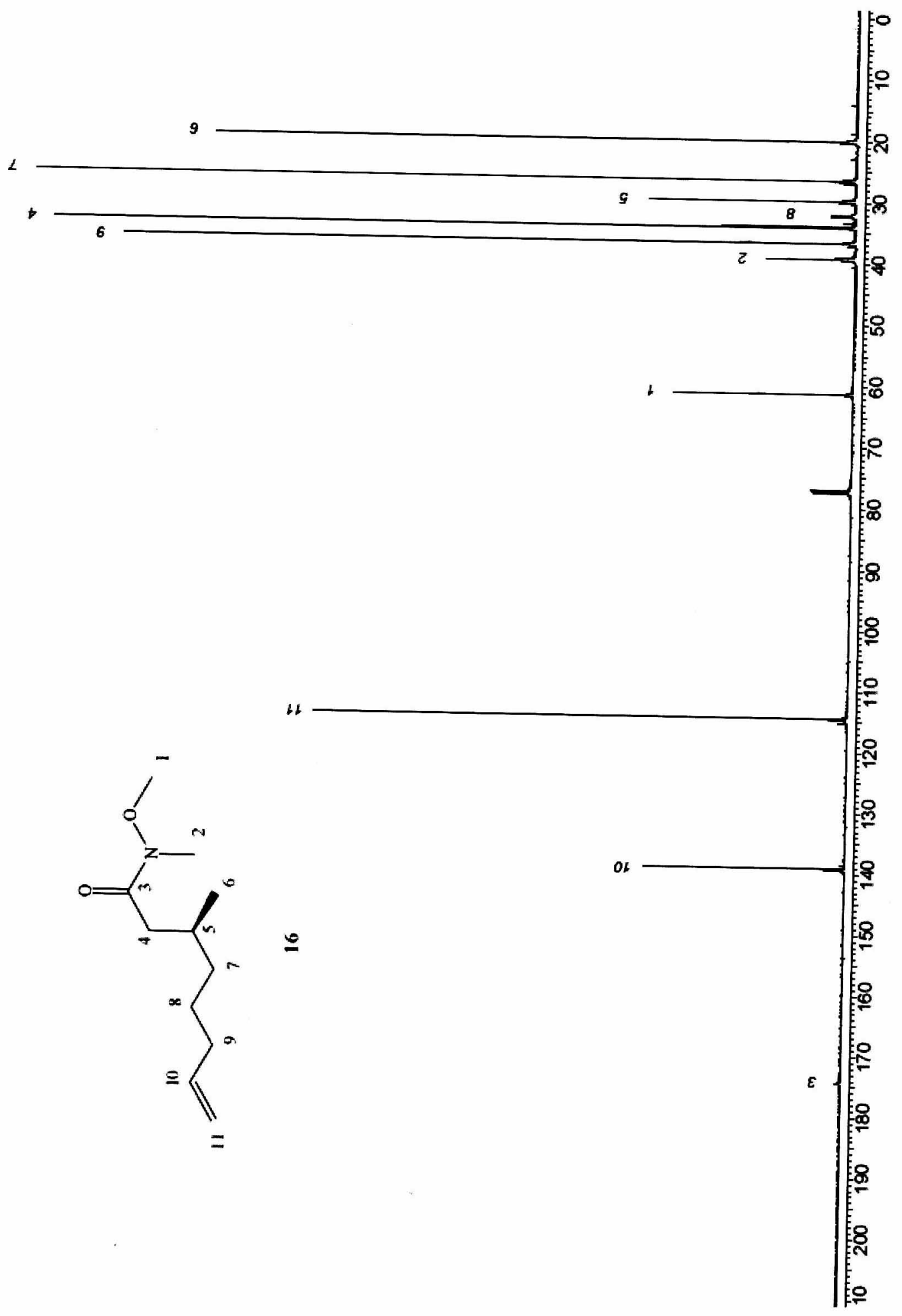




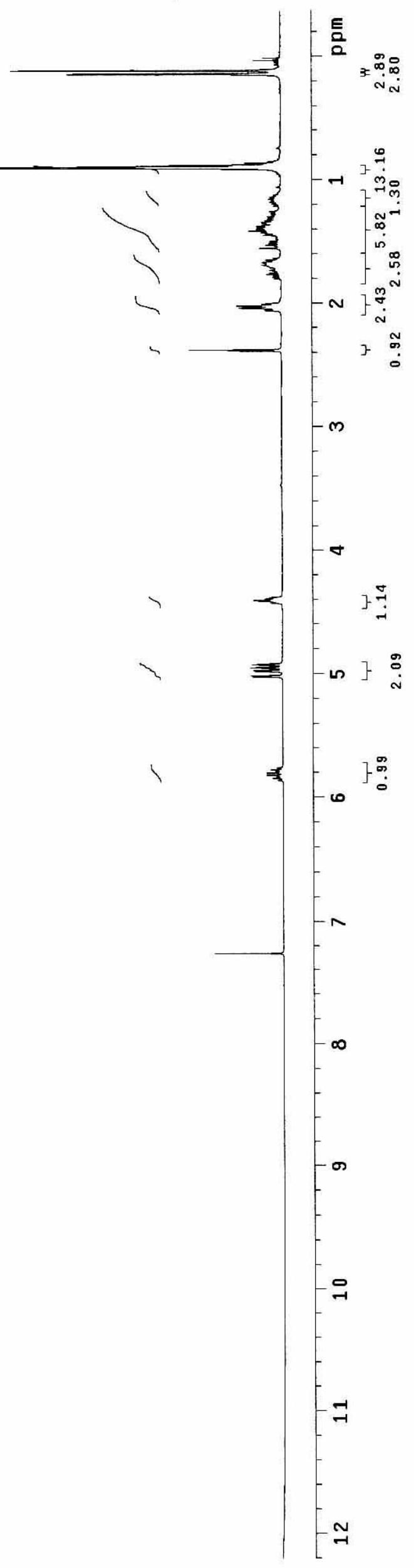

S-30 


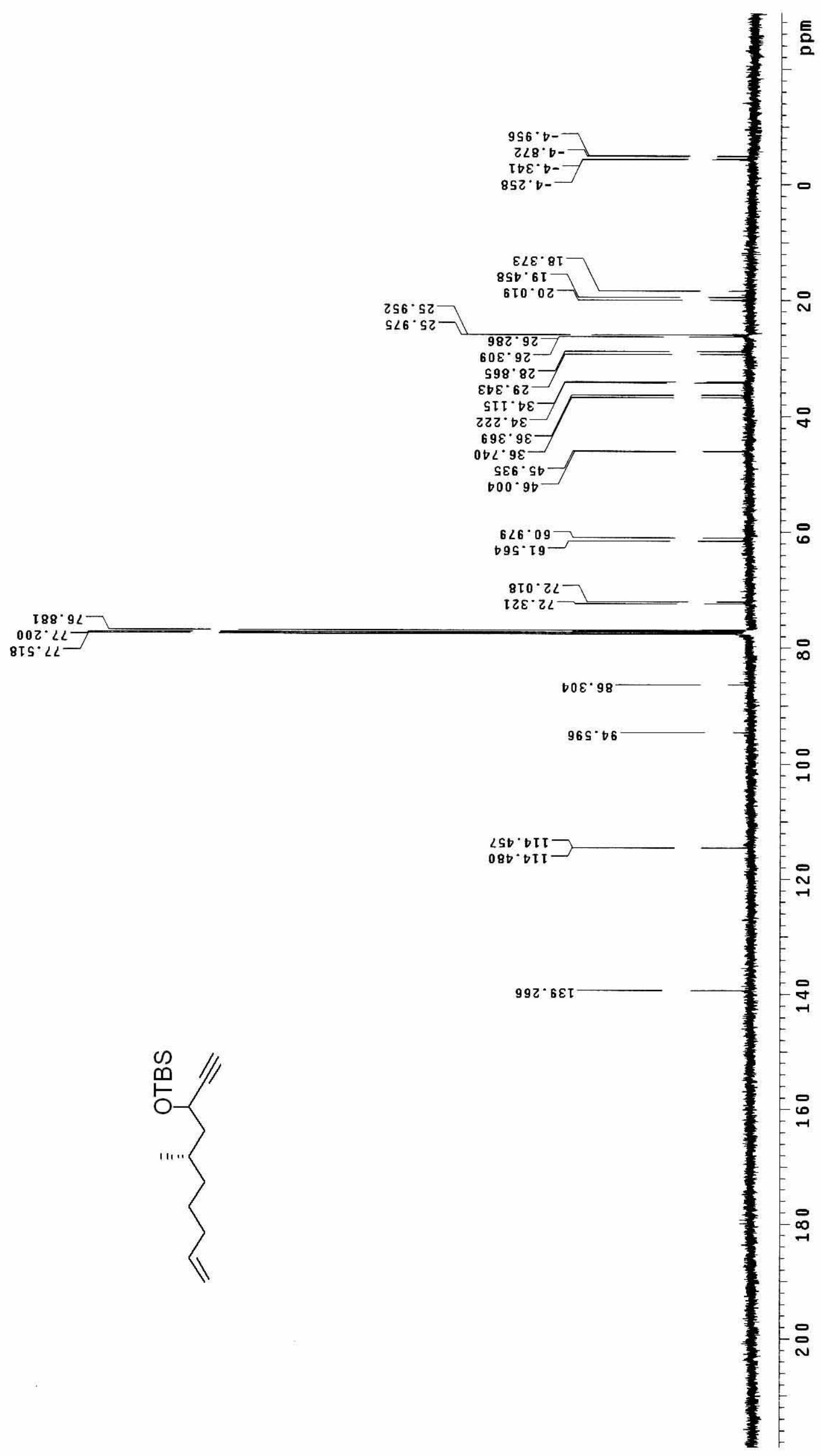




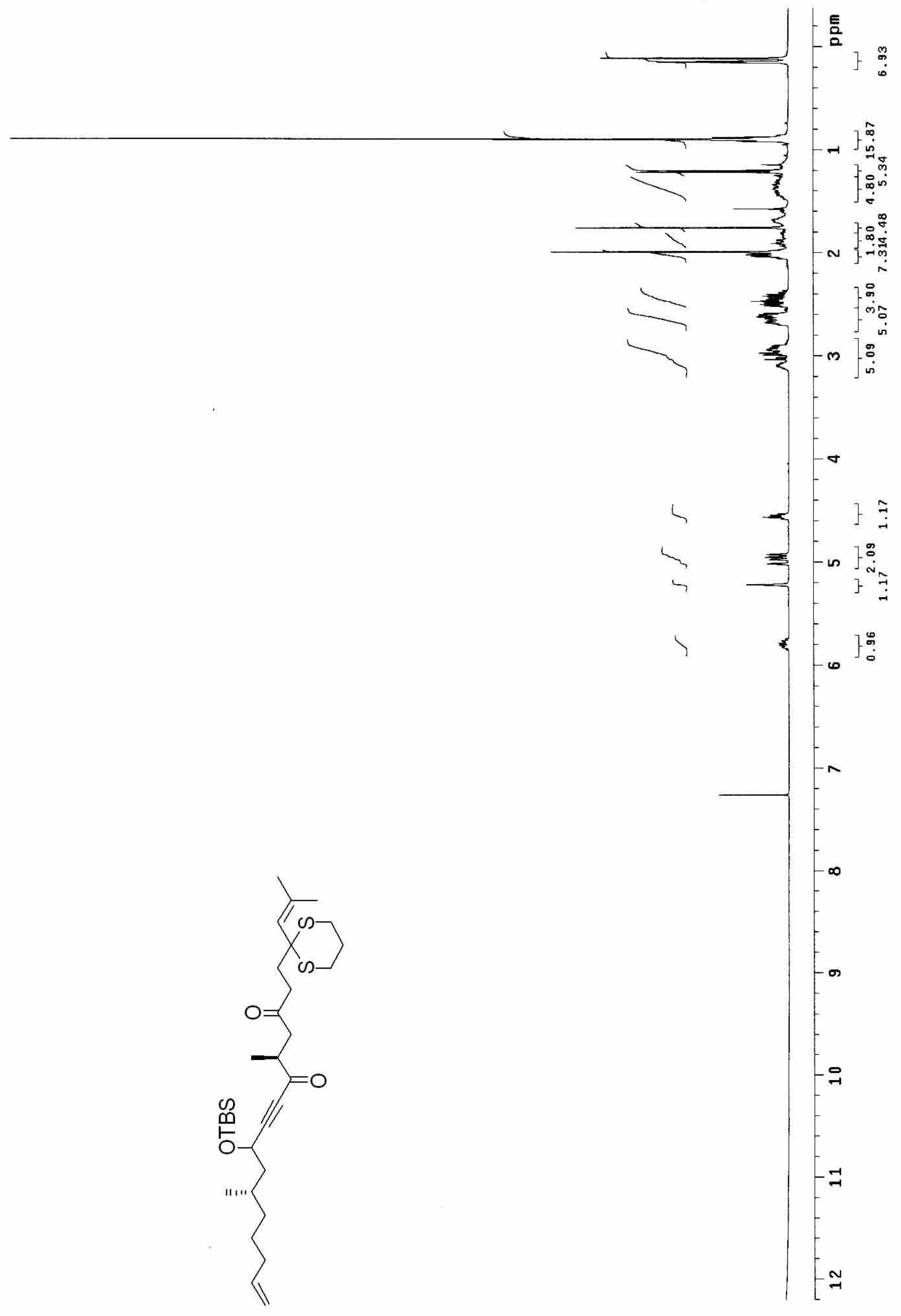



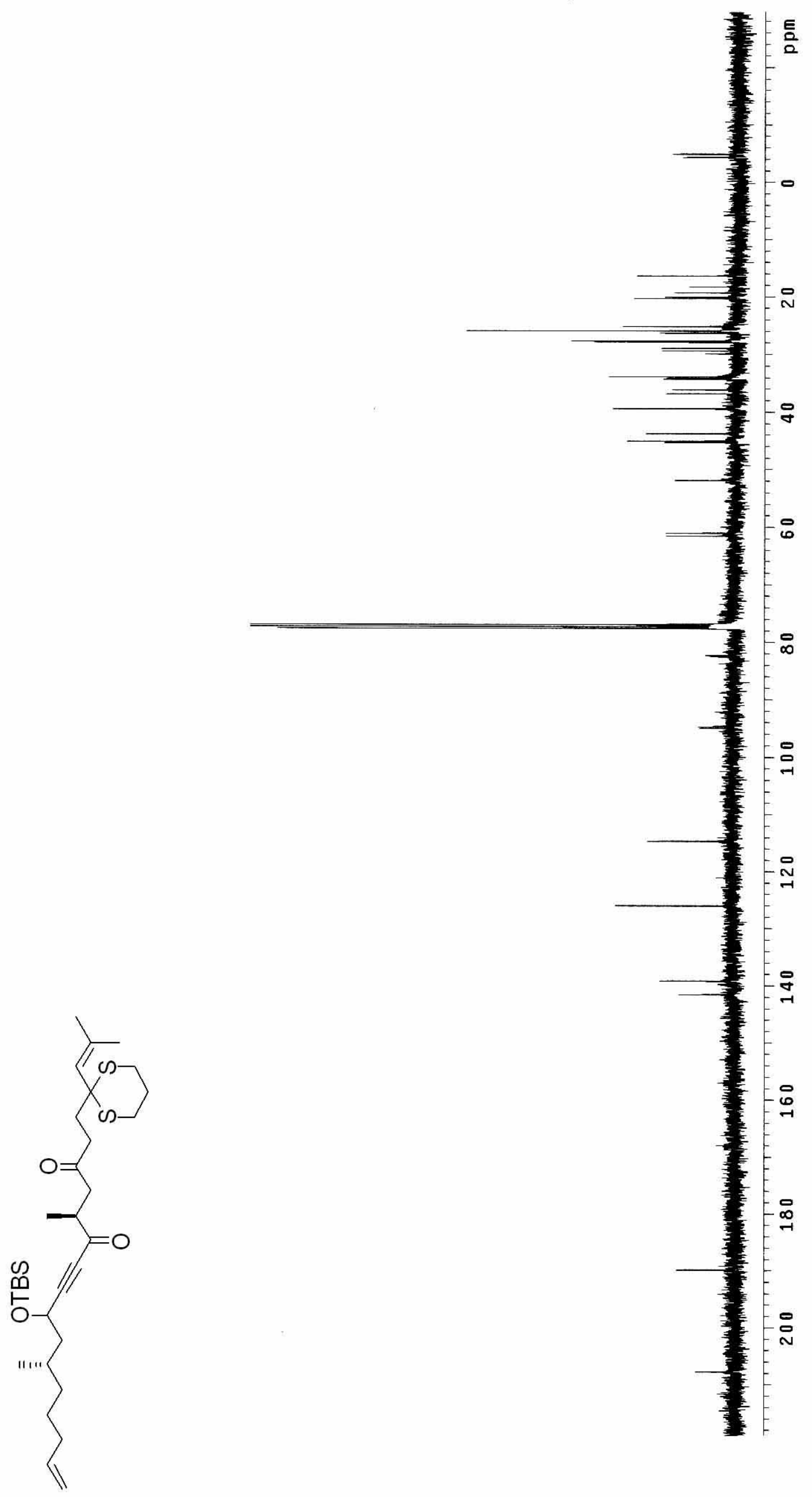


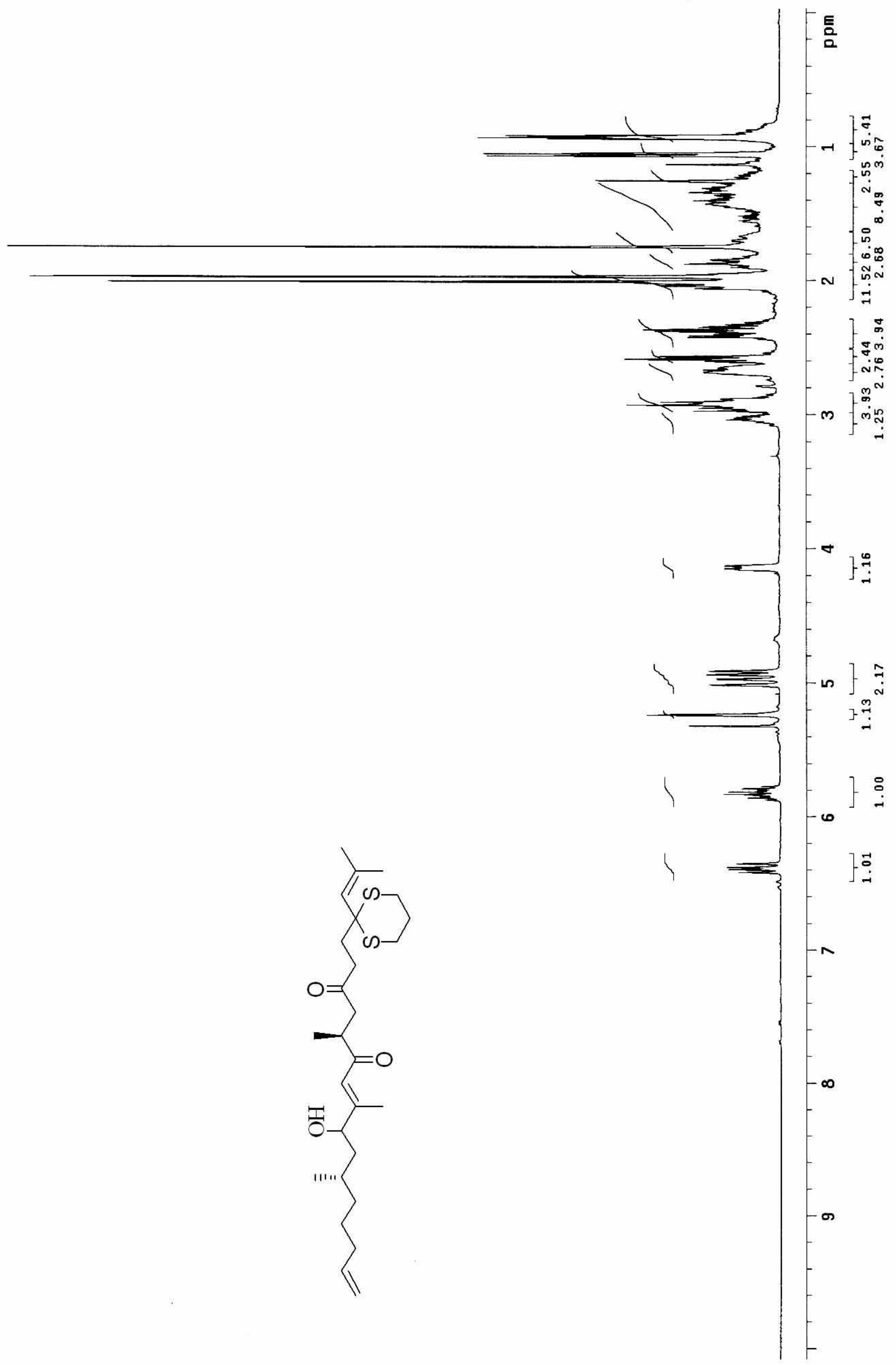




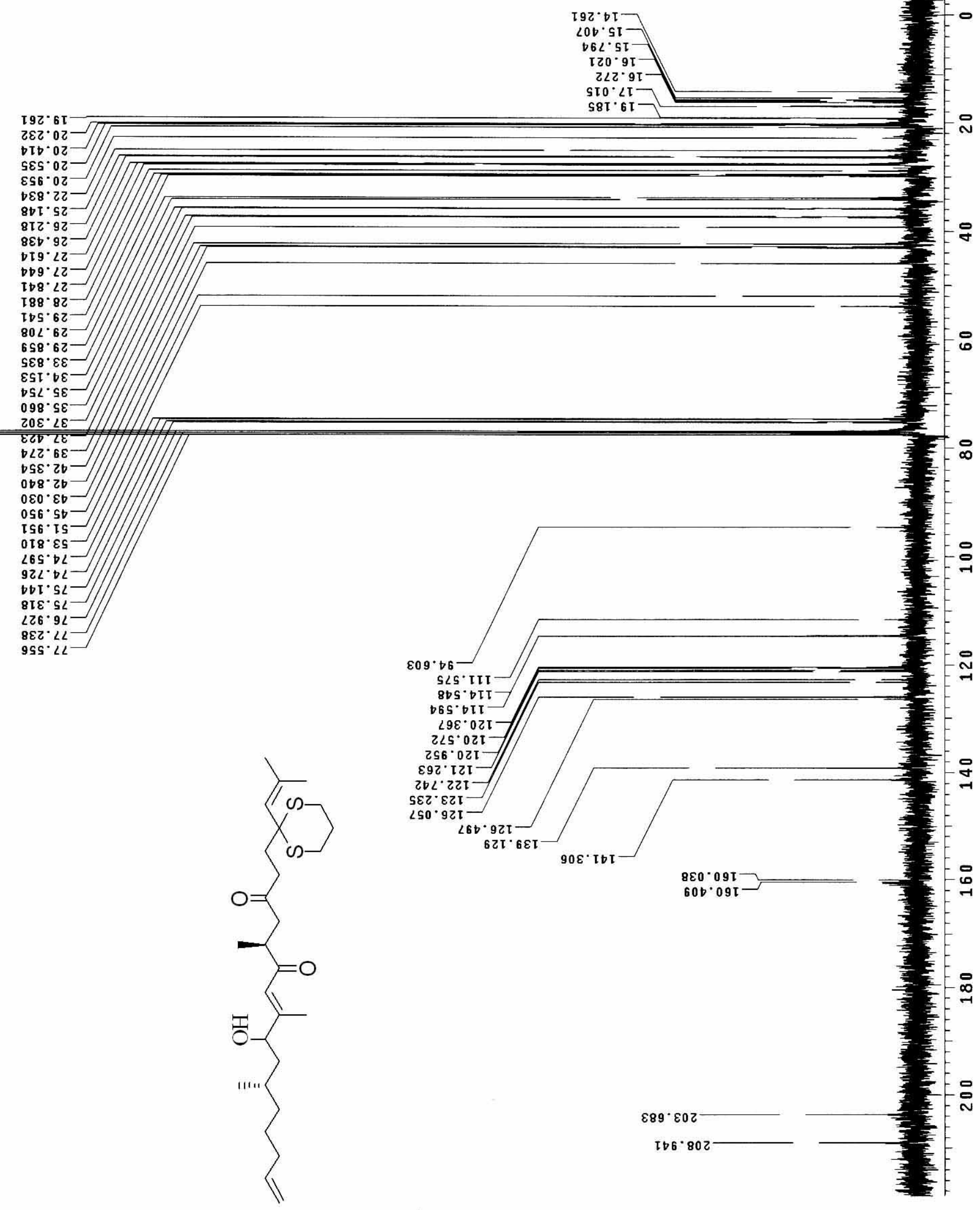




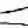

$\sim{ }^{\circ}{ }_{0}^{m}$

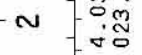

$\longrightarrow$

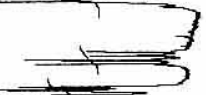

ज्ञ

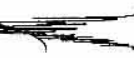

m] $\stackrel{\infty}{\dot{\varphi}}$

$\sigma$

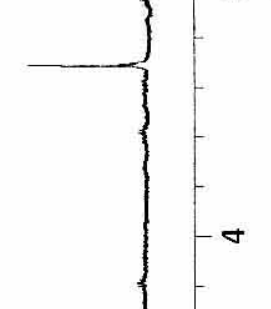

- n $\frac{i}{\text { v }}$

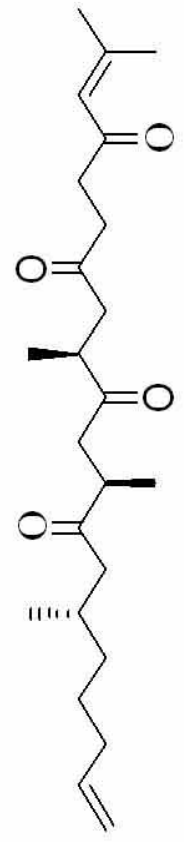

$N$

J

$\infty$

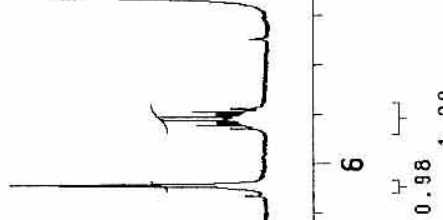




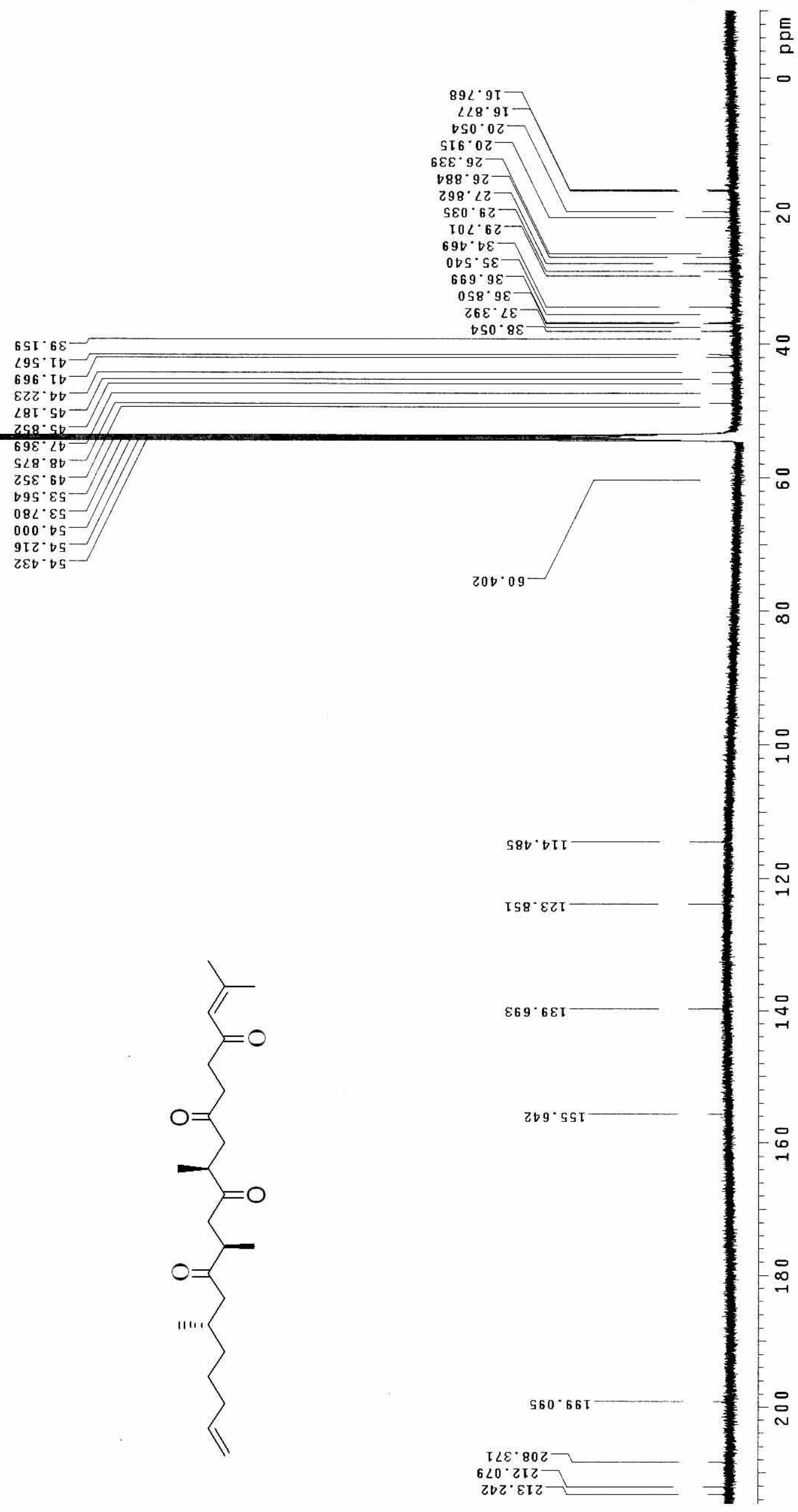

